Paper published in:

V. Sivakumar, J. Zaini, D. Gallipoli and B. Solan (2015). Wetting of Compacted Clays Under Laterally Restrained Conditions: Effects of Initial State, Overburden Pressure and Mineralogy. Géotechnique, 65(2): 111-125

http://dx.doi.org/10.1680/geot.14.P.019

Wetting of Compacted Clays Under Laterally Restrained Conditions:

Effects of Initial State, Overburden Pressure and Mineralogy

By

V Sivakumar (Queen's University Belfast)

J Zaini (ITB, Kingdom of Brunei)

D Gallipoli (Université de Pau et des Pays de l'Adour, France)

B Solan (University of Ulster)

Contact:

V Sivakumar

School of Planning, Architecture and Civil Engineering

David Keir Building

Queen's University Belfast

Belfast BT7 1NN

Email v.Sivakumar@qub.ac.uk Tel 02890974009 


\title{
Wetting of Compacted Clays Under Laterally Restrained Conditions: Effects of Initial State, Overburden Pressure and Mineralogy
}

\begin{abstract}
Compacted clay fills are generally placed at the optimum value of water content and, immediately after placement, they are unsaturated. Wetting might subsequently occur due, for example, to rainfall infiltration, which can cause volumetric deformation of the fill (either swell or collapse) with associated loss of shear strength and structural integrity. If swelling takes place under partially restrained deformation, due for example to the presence of a buried rigid structure or a retaining wall, additional stresses will develop in the soil and these can be detrimental to the stability walling elements and other building assets. Factors such as dry density, overburden pressure, compaction water content and type of clay are known to influence the development of stresses. This article investigates these factors by means of an advanced stress path testing program performed on four different clays with different mineralogy, index properties and geological histories.

Specimens of kaolin clay, London clay, Belfast clay and Ampthill clay were prepared at different initial states and subjected to "controlled" wetting whereby the suction was reduced gradually to zero under laterally restrained conditions (i.e. $K_{o}$ conditions). The results have shown that the magnitude of the increase in horizontal stresses (and therefore the increase of $K_{o}$ ) is influenced by the overburden pressure, compaction water content, dry density at the time of compaction and mineralogy.
\end{abstract}

Key words: soil suction, unsaturated soils, stress path, retaining wall 


\section{INTRODUCTION}

Compacted clay fills are usually placed at about the optimum water content (OWC) as measured from standard Proctor compaction tests. The objective is to attain the maximum dry density (MDD) corresponding to Proctor compaction, though the compaction procedures used in the field might differ from the Proctor standard. Immediately after construction, clay fills are unsaturated and, during subsequent wetting, they undergo volumetric deformation and loss of shear strength, which can in turn lead to surface settlement or heave, and even collapse or failure at saturation (Alonso et al., 1990; Clayton et al., 1991; Charles, 1993; Cui et al., 1996; Lu et al, 2004; Lloret at al., 2003; Sivakumar et al., 2010). Upon wetting, well compacted fills (i.e. engineered fills) are prone to heave whereas poorly compacted fills (i.e. un-engineered fills) are prone to settlement. Contrary to popular belief, even engineered fills can pose problems due to substantive heave at low overburden pressures (Sivakumar et al., 2010).

The deformation behaviour of unsaturated compacted clays upon wetting has been well studied within the geotechnical community. However, the impact of this deformation on buried utilities or retaining structures has received much less attention. Consider, for example, an element of compacted clay behind a retaining structure. Immediately after compaction, this element of soil is unsaturated, but subsequent rainfalls, water table fluctuations or leakage from buried utilities will increase the water content of the soil and potentially lead to saturation of the fill. This results in swelling or collapse of the fill depending on the density and state of stress within the soil. If swelling takes place under laterally restrained conditions, horizontal stresses will develop which will increase the thrust on retaining structures and potentially lead to instability (Chen, 1987; Carder, 1988; Maswoswe, 1985).

While guidelines exist for the compaction of soil fills (Design Manual for Roads and Bridges, Highways Agency, 1995; Specification for Highway Works, Highways Agency, 2004), engineers conservatively choose fill materials that can be easily analysed

and that result in minimal movements during service. This choice is driven by the client demand for assets that are resilient over a long service life, e.g. 120 years. Under restrained conditions, clay based fills produce larger stresses upon wetting than granular soils (Clayton et al. 1991). Symons (1988) reported some limited information based on field studies using different types of 
fill material and suggested that post-compaction horizontal stresses can be as high as $0.8 \times \mathrm{c}_{\mathrm{u}}$ in high plasticity clay and $0.25 \times \mathrm{c}_{\mathrm{u}}$ in low plasticity clay $\left(\mathrm{c}_{\mathrm{u}}\right.$ is the undrained shear strength of the compacted clay). In a similar study, Mawditt (1989) reported that stresses due to saturation of compacted London clay can be as high as $180 \mathrm{kPa}$ in a retaining structure supporting $6 \mathrm{~m}$ of fill, with surface heave up to $140 \mathrm{~mm}$.

The saturation dependant variation of earth pressures over time in fine grained fills is the reason why granular non-cohesive materials are generally preferred over clay. However, the use of clay fills should be promoted for two primary reasons: (a) sustained extraction of granular materials destroys green-belts and increases the emission of $\mathrm{CO}_{2}$ into the atmosphere, thus adversely impacting on the environment (b) clay materials can be often sourced close to the construction site, which reduces building costs. Yet, practicing engineers require adequate guidance about the use of compacted clay fills and on how these materials can be accommodated within current design practice.

This article presents a laboratory based investigation of the various factors that affect the behaviour of compacted clay fills upon restrained swelling. These factors include compaction effort, compaction water content, overburden pressure, plasticity index and mineralogy. The observed results are interpreted taking into account the impact of the bimodal pore size distribution which often exists in compacted clays (Delage at al., 1996; Thom et al., 2007; Monroy et al., 2010; Romero et al. 2011; Airo et al., 2012).

\section{EXPERIMENTAL WORK}

The testing programme aims to replicate the in situ behaviour of compacted fills wetted under laterally restrained deformation and constant overburden pressure. This corresponds, for example, to the case of a clay fill behind a retaining wall subjected to a constant post-construction load and to long term alterations in moisture content. This type of loading conditions can be reproduced with relative ease in a modified Rowe cell for testing unsaturated soils. However, in this equipment, side friction will develop between the sample and the inner surface of the cell, particularly when testing compacted soils. Brown and Sivakumar (2008) carried out a series of tests on un-engineered and engineered compacted kaolin using a modified Rowe cell to test 
unsaturated soils. The cell was instrumented with pressure cells at the base and on the side wall at mid height. The samples were saturated from the bottom. Figure 1 shows the average vertical pressure at mid height (the average of the pressure applied at the top and measured at the base) for a given overburden pressure applied to the top. The diagram confirms that the average pressure at mid height was not constant (due to significant variation of vertical pressure measured at the base close to the wetting front) during wetting. This complicated the assessment of the coefficient of earth pressure at rest $\left(K_{o}\right)$. The reasons for such variations of vertical pressure are discussed in Brown and Sivakumar (2008). Based on these results, in the present investigation it was decided that a more accurate option would be the use of a stress path cell. The testing system employed in this research is the same as the one used by Boyd and Sivakumar (2011). These authors gave a complete description of sampling and testing procedures, so only a summary is presented here.

\section{Sampling}

Four different materials were used in the present research, namely commercial Kaolin Clay (KC) supplied by WhitChem Ltd, UK, and three natural clays that have been or could be used for backfilling (Mawditt, 1989), i.e. London Clay (LC), Ampthil Clay (AMT) and Belfast Upper Boulder Clay (BC). The physical characteristics, plasticity classification, and mineralogy of these clays are presented in Table 1. LC has the lowest percentage of clay size particles, yet is classified as very high plasticity clay as of AMT. KC is high plasticity and BC is classified as an intermediate to high plasticity clay. $\mathrm{KC}$ and $\mathrm{BC}$ are non-expansive whereas LC and AMT contain a very small amount of expansive minerals. AMT clay also contains about $6 \%$ organic content.

Natural soils are deposited under one-dimensional loading conditions. However, when the soil is excavated and re-compacted to form different landscapes, the loading process might no longer be one-dimensional. This is because fills are typically compacted by means of wheels or rollers that have finite horizontal dimensions. There is limited information available in the literature regarding the degree of anisotropy of compacted fills. Any attempt to prepare compacted samples in the laboratory with the same characteristics as in the field will involve significant uncertainties and will complicate the interpretation of test results. For that reason, in this work, specimens were isotropically compacted, which ensured isotropic material properties prior to wetting under laterally restrained conditions. 
Tests were undertaken in a stress path apparatus on cylindrical specimens of $50 \mathrm{~mm}$ diameter and $50 \mathrm{~mm}$ height prepared using the following procedure as suggested by Boyd and Sivakumar (2011). The three natural soils (LC, BC and AMT) were dried at $80{ }^{\circ} \mathrm{C}$, crushed and passed through a $425 \mathrm{~m} \mu$ sieve (Kaolin was already available in powder form). The dry powders of the four clays were mixed with water at a target moisture content (relative to the Proctor optimum), before being sieved through a $1.18 \mathrm{~mm}$ aperture mesh. A rubber membrane was then placed around the $100 \mathrm{~mm}$ diameter pedestal of a standard triaxial cell and sealed at the base using two 'O'-rings. A stretcher was placed around the membrane and the top of the membrane was folded around the top of the stretcher. A $100 \mathrm{~mm}$ diameter dry porous filter was placed on the pedestal and the mixed sieved material was filled slowly into the membrane, until a height of $150 \mathrm{~mm}$ was achieved. Thereafter, another dry porous filter was placed above the material, followed by the top cap against which the membrane was sealed by 'O'-rings. The purpose of the dry filters was to allow drainage of air (and water, if any) from the top and bottom of the sample during compaction. The cell was assembled and the required cell pressure (based on the target dry density as explained later) was applied and maintained for 3 days while allowing pore air/water drainage. The isotropically compacted sample was then dismantled and a specimen of $50 \mathrm{~mm}$ diameter and $50 \mathrm{~mm}$ height was extruded using a thin walled sampler.

Specimens were prepared at different water contents and compaction pressures. Table 2 lists the compression pressures, water contents and initial suctions (i.e. suctions measured after compaction by using a psycrometer) for the different materials. For each material type, one or more specimens were prepared and details of the initial conditions are given in Table 3 . Ten KC specimens were prepared for the main testing program and their initial dry densities and water contents are shown in Figure 2 together with the standard Proctor compaction curve. The classification of specimens in heavily engineered, engineered, poorly engineered or unengineered (Table 2) reflects the initial state of the specimens relative to the standard Proctor curve. Heavily engineered, engineered, poorly engineered and un-engineered specimens have dry densities that are higher, equal, lower and much lower than standard Proctor, respectively.

The static isotropic pressure required for preparing engineered $\mathrm{KC}$ specimens (i.e. specimens with the same densities as standard Proctor) was obtained from the pressure-density relationship 
of statically compacted $\mathrm{KC}$ at $25 \%$ water content and was found to be $1200 \mathrm{kPa}$. The pressuredensity relationship was measured by isotropically compressing $\mathrm{KC}$ at $25 \%$ water content inside a twin-cell (Sivakumar et al. 2010) where water flow into the inner cell allowed measurement of the soil volume change. The same pressure of $1200 \mathrm{kPa}$ was also used for preparing samples of the other three natural clays, which resulted however in heavily engineered samples with considerably higher dry densities than the respective Proctor curves (Figure 3).

\section{Experimental methodology}

A stress path cell was modified to allow suction control by means of the axis translation technique (Hilf, 1958). The software TRIAX (Toll, 1999) was used to maintain a constant net axial stress by regulating the lower chamber pressure while the cell pressure was adjusted to maintain a condition of zero radial strain throughout the wetting process. Axial and radial strains were measured using specimen-mounted inclinometers and miniature linear voltage differential transducers (LVDT), respectively. The radial strain gauge was located at mid height of the specimen, $25 \mathrm{~mm}$ above the base where water drainage was permitted.

The control of radial strain was achieved through a feed-back loop based on the measurement of radial deformation at the mid-height of the specimen. Initially, this posed some concerns as the deformation at mid-height might not be representative of the deformation at other heights along the specimen. Indeed the bottom of the specimen (which is closer to the water drainage) responds immediately after the start of wetting but some time will elapse before any response is observed at mid height. In order to further explore this issue some preliminary tests were performed. Figure $4 \mathrm{a}$ presents the results from a wetting test where the suction was brought zero in a single step from its initial value (about $1300 \mathrm{kPa}$ ) to zero (saturated conditions). It shows the normalized flow (i.e. the cumulative amount of water inflow to the specimen normalized by the total volume of water inflow at saturation) plotted against root time. With a standard filter (air entry value close to zero) the saturation process lasted about 10 hours; however, when a 15 bar air entry value filter was used, the time increased to 140hours. This indicates that the flow though the unsaturated specimen is significantly affected by the low permeability of the high air entry filter. Such a response could be considered as "negative" if the study was aimed at measuring the permeability of the soil. In the present case, however, it aids the uniform equalization of water 
content along the specimen by slowing the wetting process. Further evidence of this is shown in Figure $4 \mathrm{~b}$, which shows the readings from two radial strain gauges located at $12.5 \mathrm{~mm}$ and 25 $\mathrm{mm}$ above the base (where water drainage is permitted). The observations show that the time lag between the responses of the two lateral strain gauges is just under $1 \mathrm{hr}$. This period is considerably smaller than the duration of wetting stage of the tests carried out under laterally restrained conditions in the main testing programme. Also note that the differences in deformation at any given time are not significant. In addition, with regard to the investigation presented in Fig 4b, no attempt was made to measure the lateral strain at the top of the sample, however it is expected that the difference in radial strains between the middle and top of the sample is of the same order of magnitude as the measured difference between the bottom and middle of the sample. Therefore, although the adopted experimental procedure can only enforce rigorous zero radial strain condition at the middle of the sample, it can be reasonably assumed that the measured value of the coefficient of earth pressure at rest $\left(K_{o}\right)$ must not be very different from its true value that would be measured in the ideal case where a radial strain of exactly zero was maintained throughout the height of the sample."

In the event of an increase in cell pressure (to counteract lateral expansion of the specimen), a constant vertical net stress $\overline{\sigma_{v}}$ was maintained by reducing the lower chamber pressure, thus applying a negative deviator stress. This required a special connection on the top cap of the specimen for the application of a tensile load. Further details of experimental arrangement are detailed in Boyd and Sivakumar (2011).

The specimens were initially equalized in the triaxial cell at a suction of $400 \mathrm{kPa}$ (this was the highest value of suction that could be imposed during equalization due to the limitations of the compressed air supply which could attain a maximum pressure of $750 \mathrm{kPa}$ ). In general, the equalization took place under an axial net stress of $50 \mathrm{kPa}$, though the axial net stress was $25 \mathrm{kPa}$ or $100 \mathrm{kPa}$ in a small number of tests. Radial deformation was not restricted during the initial equalization and therefore the radial stress was equal to the vertical stress. The equalization stage led to an axial swelling of approximately $0.25-0.75 \%$ depending on soil type, initial water content and dry density. 
Subsequently, suction was gradually reduced to zero under radially restrained conditions. Unlike Boyd and Sivakumar (2011), who wetted the specimens in a single step to a target suction value, suctions were here reduced in multiple steps of, generally, 50kPa. The equalization time during each step was 3-4 days for KC and 5-6 days for LC, BC and AMT. This procedure had the advantage of providing a continuous measurement of the radial net stress along the wetting path and significantly reduced fluctuations in the measurement of $K_{o}$ (a typical example of this multisteps wetting process is shown in Figure 5). In each step, wetting was considered completed when the water flow into the specimen was less than $0.02 \mathrm{~cm}^{3} /$ per day $(0.05 \%$ water content). The type of tests carried out on $\mathrm{KC}$ and the three other natural clays are listed in Table 3.

In saturated soils, the coefficient earth pressure $K_{o}$ is defined as the ratio between horizontal and vertical effective stresses "at rest" (no lateral straining). This definition is here extended to unsaturated soils in terms of net stresses:

$$
K_{o}^{*}=\frac{\sigma_{h}-u_{a}}{\sigma_{v}-u_{a}} \quad \text { Equation } 1
$$

where $\sigma_{v}, \sigma_{h}$, and $u_{a}$ are the total vertical stress, total radial stress and pore air pressure, respectively. The symbol $K_{o}^{*}$ is used to differentiate it from the coefficient of earth pressure of saturated soils, $K_{o}$.

Figure 6 shows the results from three preliminary tests $(\mathrm{KC} 8, \mathrm{KC} 15$ and $\mathrm{KC} 16)$ which were performed to explore the swelling/collapse properties of $\mathrm{KC}$ upon wetting with and without restriction of radial strains. The $\mathrm{KC} 8$ specimen, which was subjected to radially restrained conditions and a constant overburden pressure of $50 \mathrm{kPa}$, swelled axially up to $5.4 \%$. The $\mathrm{KC} 15$ specimen, which was subjected to $100 \mathrm{kPa}$ of axial net stress and $50 \mathrm{kPa}$ of radial net stress, swelled radially by $2.6 \%$ and axially up to a maximum value of $0.3 \%$ during the first part of wetting (up to a suction of about $50 \mathrm{kPa}$ ), followed by collapse compression (i.e. settlement) as saturation was approached. This specimen was subjected to an anisotropic stress state, so part of the strain occurring at low suctions was caused by the soil yielding closer to critical state. At higher suctions, the sample swelled more in the radial direction than in the axial one, implying a preference for the aggregates to expand in the direction subjected to the smallest confining stress (Boyd and Sivakumar, 2011). Finally, the specimen KC16 was subjected to wetting under both 
axial and radial net stress of $50 \mathrm{kPa}$ (i.e. isotropic stress state). The specimen swelled radially about $4.1 \%$ and axially somewhat less $(2.1 \%)$ despite the fabric of the material was ostensibly isotropic.

Although this study focuses on the wetting behaviour of soils under radially restrained deformation and constant overburden pressure, a limited number of tests were also conducted to examine the behaviour during loading at constant suction. To this end, some $\mathrm{KC}$ specimens were wetted to suctions of zero, $150 \mathrm{kPa}$ and $300 \mathrm{kPa}$ under radially restrained conditions and subsequently loaded at constant suction still under radially restrained conditions. Other $\mathrm{KC}$ specimens were initially wetted to target suctions of $300 \mathrm{kPa}, 150 \mathrm{kPa}$ and zero without any

restriction on lateral strain and subsequently taken through stress paths with $\Delta q / \Delta \bar{p}=0$ (isotropic), $\Delta q / \Delta \bar{p}=-3 / 2$ and $\Delta q / \Delta \bar{p}=-\infty$, where $q$ and $\bar{p}$ are the deviator and mean net stress respectively. The relevant test numbers are listed in Table 4. These additional tests were used to interpret soil behaviour in terms of the constitutive framework proposed by Sivakumar et al. (2010).

\section{RESULTS AND DISCUSSION}

The results of the wetting tests under radially restrained conditions are here discussed according to the following headings:

- Effect of compaction water content (studied on KC)

- Effect of compaction effort (studied on KC)

- Effect of overburden pressure (studied on $\mathrm{KC}$ )

- Effect of clay mineralogy (studied on KC, LC, BC and AMT)

A brief summary of the effects of material fabric on volume change behaviour is first given here in order to aid the discussions later. Compacted clays possess a bimodal pore size distribution (Delage et al., 1996; Thom et al., 2007; Romero et al., 2011; Airo Farulla et al., 2012 and Monroy et al., 2010). At small (micro) scale the individual clay particles form aggregates which are held together by suction while, at the larger (macro) scale, these aggregates are assembled to create a higher porous structure. The wetting-induced change of pore volume inside and between 
aggregates produces swelling or collapse of the unsaturated soil. Wetting of compacted clays will result in two different volumetric responses: swelling of aggregates and collapse compression due to aggregate slippage (Sivakumar et al. 2010). The overall volumetric response is determined by which of the above two forms of behaviour is the predominant one. Thom et al. (2007), Romero et al. (2011) and Airo Farulla et al. (2012) presented evidence that, in a poorly compacted fill subjected to wetting at low overburden pressures, the clay aggregates expand into the interaggregate voids, therefore, reducing the overall volume. Conversely, in a heavily compacted fill, due to the lack of inter-aggregate volume, any wetting induced expansion of the aggregates, translates directly into overall swelling. Monroy et al. (2010) presented conclusive evidence that wetting of compacted London Clay to saturation (zero suction) generally eradicates the bimodal pore size distribution, with a large part of the change in soil fabric taking place between suctions of $40 \mathrm{kPa}$ to zero.

\section{Effects of compaction water content (KC)}

Three tests were conducted on engineered $\mathrm{KC}$ specimens compacted at water contents of $8 \%$ $(\mathrm{KC} 12), 5 \%(\mathrm{KC} 8)$ and $2 \%(\mathrm{KC} 13)$ drier than the optimum value of $30 \%$. Figure 7 a shows the increase in specific water volume against suction for these specimens. The initial values of specific water volume were 1.598, 1.679 and 1.759 for $\mathrm{KC} 12, \mathrm{KC} 8$ and $\mathrm{KC} 13$, respectively (Table 3) while the increases of specific water volume at saturation (i.e. for suction equal to zero) were $0.531,0.394$ and 0.241 . The starting point of each curve corresponds to the amount of water intake during the initial equalization stage at a suction of $400 \mathrm{kPa}$. It should be noted that intake of water during saturation increases with reducing water content at compaction. Therefore a larger water intake should have been observed for specimen $\mathrm{KC} 12$ prepared at $22 \%$ water content in comparison with specimens $\mathrm{KC} 8$ and $\mathrm{KC} 13$ prepared at $25 \%$ and $28 \%$ water content, respectively. This however is only true below the suction of $200 \mathrm{kPa}$ whereas during the early stage of wetting, i.e. between suctions of 400 and $200 \mathrm{kPa}$, the water intake of specimen KC12 appears very small. This may have been caused by the loss of water continuity between specimen KC12 and the ceramic filter, which may have also affected other aspects of the specimen responses such as the development of radial stresses and axial swelling. 
Figure $7 \mathrm{~b}$ shows the change in radial net stresses against suction caused by the imposition of zero radial strains. The stress increased at the start of wetting, implying that the specimens tended to expand radially. The rate of increase in radial net stress is considerable in the case of specimen $\mathrm{KC13}$, which was prepared at a water content of $28 \%$ and moderate in the case of specimen $\mathrm{KC} 8$, which was prepared at a water content of $25 \%$. The initial dry density of $\mathrm{KC} 13$ is $6 \%$ higher than that of $\mathrm{KC} 8$, suggesting that $\mathrm{KC} 8$ would have had larger macro voids into which the aggregates could expand upon wetting (Thom et al. (2007)). As explained earlier, the specimen KC12 prepared at $22 \%$ water content might have experienced a loss of hydraulic contact with the ceramic filter at high suction values and this is also reflected in the measurements of radial stresses. The reduced intake of water by the specimen implies that the actual suction in the specimen was higher than the target suction and consequently the specimen was much stiffer during the early stages of wetting, i.e. between 400 and 200kPa (Fig 7c). Therefore any radial deformation of the specimen would have triggered significant increase in radial stress. This explains why the radial stress-suction curve for $\mathrm{w}=22 \%$ lies above that for $25 \%$ between the suction values of 200 and $400 \mathrm{kPa}$. The trend observed below 200kPa of suction appears consistent for all three specimens. For all specimens, the radial net stress increased upon wetting and attained a maximum value at an intermediate level of suction followed by a reduction to about $90 \mathrm{kPa}$ upon saturation. The above observations can be re-interpreted in terms of $K_{o}^{*}$ (note that the axial net stress was constant at $50 \mathrm{kPa}$ ) and a summary of the values of $K_{o}^{*}$ measured in all tests is given in Table 5.

Figure 7c shows the axial strain plotted against suction for specimens $\mathrm{KC12}, \mathrm{KC} 8$ and $\mathrm{KC} 13$. The starting point of each curve corresponds to the axial swelling undergone by the specimen during the initial equalization stage at a suction of $400 \mathrm{kPa}$ (recall that for specimen $\mathrm{K} 12$ a loss of contact between the soil and the ceramic filter might have occurred during the initial stages of wetting). Therefore the axial swelling at the end of equalization was $0.1 \%$ for $\mathrm{KC} 12$ and increased to $0.3 \%$ and $0.6 \%$ for KC13 and KC8, respectively. Specimens KC8 and KC13 swelled by similar magnitudes during wetting under radially restrained deformation and the axial strain at saturation was about $5.4 \%$ in both cases. In the case of $\mathrm{KC} 12$, the axial swelling was less ( 4.0\%). Dry density of KC13 was higher than $\mathrm{KC} \mathrm{8,} \mathrm{implying} \mathrm{that} \mathrm{KC13} \mathrm{could} \mathrm{swell} \mathrm{more} \mathrm{than}$ $\mathrm{KC} 8$ due to lack of inter aggregate voids. A counteracting factor is that the initial suction in $\mathrm{KC}$ 
13 was much lower than that of $\mathrm{KC} 8$. In addition, $\mathrm{KC} 13$ experienced much higher lateral stresses than KC8. These combined effects have resulted in similar amount of axial swelling for KC13 and $\mathrm{KC} 8$ upon saturation.

The above comparisons refer to three specimens compacted at similar levels of effort as the standard Proctor but different water contents. However, the initial dry density of these three specimens increases with increasing values of compaction water content. In order to investigate the effect of compaction water content at constant dry density, a comparison is made between tests $\mathrm{KC} 5$ and $\mathrm{KC} 12$ where the initial dry densities are reasonably similar but the compaction water contents are $22 \%$ and $25 \%$, respectively. Figure 8 shows that that the radial stresses (or the value of $K_{o}^{*}$ ) developed upon wetting tend to be higher as the compaction water content is reduced for a given initial dry density. This is because drier fills have higher values of initial suctions (Table 2) and, accordingly, a higher tendency to swell upon wetting.

\section{Effects of compaction effort (Kaolin Clay)}

The swelling potential of clay fills upon wetting is significantly influenced by compaction energy (Sivakumar et al., 2010 and Schanz et al., 2009). For example, heavily engineered fills exhibit larger swelling than un-engineered fills even if compacted at the same water content, which has in turn an influence on the radial pressures generated under radially restrained conditions. This aspect was examined in this work by performing wetting tests on four $\mathrm{KC}$ samples compacted at the same water content (25\%) but under variable overburden pressures. The four specimens have different initial dry densities of $1.19 \mathrm{Mg} / \mathrm{cm}^{3}$ (KC14), $1.25 \mathrm{Mg} / \mathrm{cm}^{3}$ (KC5), $1.32 \mathrm{Mg} / \mathrm{cm}^{3}$ (KC8) and $1.36 \mathrm{Mg} / \mathrm{cm}^{3}$ (KC11) and are here categorised as: un-engineered, poorly engineered, engineered and heavily engineered. The initial suctions measured after sampling are listed in Table 2. Although specimens were compacted at the same water content (i.e. 25\%), suction tends to reduce with increasing compaction effort.

During wetting, the specific water volume increased by $0.365,0.406,0.451$ and 0.380 for samples $\mathrm{KC} 14, \mathrm{KC} 5, \mathrm{KC} 8$ and $\mathrm{KC} 11$, respectively (Figure 9a). Figure 9b shows that, for all samples, the radial net stress increased up to a maximum value between suctions of $200 \mathrm{kPa}$ and $300 \mathrm{kPa}$ (except for sample $\mathrm{KC} 8$ which attained a maximum value of radial net stress for a suction 
between $100 \mathrm{kPa}$ and $200 \mathrm{kPa}$ ) before reducing as the soil approached saturation. In the case of the un-engineered specimen $\mathrm{KC} 14$, the radial net stress slowly increased to a maximum of $69 \mathrm{kPa}$ before falling to $57 \mathrm{kPa}$ at full saturation. For the poorly engineered specimen $\mathrm{KC} 5$, the radial net stress increased to a maximum of $91 \mathrm{kPa}$ before reducing to $80 \mathrm{kPa}$. Finally, in the case of the engineered and heavily engineered specimens $\mathrm{KC} 8$ and $\mathrm{KC} 11$, the maximum radial net stresses were $97 \mathrm{kPa}$ and $137 \mathrm{kPa}$, respectively, while the radial net stresses at saturation were $90 \mathrm{kPa}$ and $110 \mathrm{kPa}$. The corresponding maximum values of the coefficient, $K_{o}^{*}$ are listed in Table 5. During wetting, all specimens swelled axially by different amounts (Figure 9c). The magnitude of swelling was about $0.5 \%$ axial strain for the un-engineered specimen $\mathrm{KC} 14$ and was as high as $6.7 \%$ for the heavily engineered specimen $\mathrm{KC} 11$. The observed behaviour is therefore consistent with the postulation of volumetric behaviour of compacted clays possessing a bimodal pore size distribution, as discussed earlier.

\section{Effects of overburden pressure (Kaolin Clay)}

Three engineered specimens ( $\mathrm{KC} 7, \mathrm{KC} 8$ and $\mathrm{KC} 9)$ were compacted at a water content of $25 \%$ and a dry density of about $1.32 \mathrm{Mg} / \mathrm{cm}^{3}$. Similarly to previous tests, the specimens underwent wetting from a suction of $400 \mathrm{kPa}$ under radially restrained conditions but, in this case, they were subjected to axial net stresses of different magnitudes equal to $25 \mathrm{kPa}, 50 \mathrm{kPa}$ and $100 \mathrm{kPa}$ for $\mathrm{KC7}, \mathrm{KC} 8$ and $\mathrm{KC}$, respectively, to represent various depths of fill behind retaining structures. In the case of $\mathrm{KC} 9$, the suction was reduced from $400 \mathrm{kPa}$ to $300 \mathrm{kPa}$ in single step and then by $50 \mathrm{kPa}$ steps until complete saturation.

Figure 10a shows the measured values of radial net stress against suction for all three specimens. For specimens $\mathrm{KC} 7$ and $\mathrm{KC} 8$, the maximum radial net stresses of $90 \mathrm{kPa}$ and $97 \mathrm{kPa}$, respectively were attained at suctions between $100 \mathrm{kPa}$ and $200 \mathrm{kPa}$ while, for specimen $\mathrm{KC}$, the maximum horizontal net stress of $145 \mathrm{kPa}$ was attained close to zero suction (i.e. close to saturation). Upon full saturation, the horizontal net stresses reduced to $71 \mathrm{kPa}, 94 \mathrm{kPa}$ and $141 \mathrm{kPa}$ for specimens $\mathrm{KC} 7, \mathrm{KC} 8$ and $\mathrm{KC}$, respectively. Figure $10 \mathrm{~b}$ shows that the coefficient $K_{o}^{*}$ reached a maximum of 3.60 in the case of specimen $\mathrm{KC} 7$, which was subjected to an overburden pressure of $25 \mathrm{kPa}$ 
(corresponding to a relatively shallow depth of the fill). The relevant values of $K_{0}^{*}$ are listed in Table 5.

\section{Effects of clay mineralogy}

Additional tests were conducted on three natural clays, i.e. London Clay (LC), Belfast Clay (BC) and Ampthill Clay (AMT). For each clay type, two heavily engineered specimens were compacted at two water contents, i.e. $15 \%$ and $18 \%$ for LC, $17 \%$ and $20 \%$ for BC and $22 \%$ and $25 \%$ for AMT (Table 3). LC, BC and AMT are natural materials with different index properties and Proctor optimum water contents of $23 \%, 24 \%$ and $29 \%$ respectively. Therefore the differences between compaction water contents and optimum water contents were relatively similar to those for $\mathrm{KC}$.

London Clay: The suctions measured after sampling were $1593 \mathrm{kPa}$ for sample LC1 compacted at a water content of $15 \%$ and $1306 \mathrm{kPa}$ for sample LC3 compacted at a water content of $18 \%$. Figure 11a shows the water intake during wetting while Figure $11 \mathrm{~b}$ shows the corresponding change of radial net stress. For both samples, the radial net stress increased rapidly at the beginning of wetting and attained the maximum value for suctions between $100 \mathrm{kPa}$ and $200 \mathrm{kPa}$ (Figure 11b). In the case of the drier sample LC1, the attainment of full saturation resulted in a relaxation of the radial net stresses. The same was not true for the wetter sample LC3 (compacted at water content close to optimum) which instead experienced only a small reduction in horizontal net stress as saturation approached. The observed behaviour is in general agreement with the full scale study reported by Mawditt (1989) who reported lateral stress of as high as $180 \mathrm{kPa}$ in $6 \mathrm{~m} \mathrm{LC}$ fill. The corresponding values of the coefficient $K_{o}^{*}$ are listed in Table 5. Contrary to $\mathrm{KC}$, the drier specimen LC1 experienced a higher axial swelling of $6.6 \%$ upon saturation than the wetter specimen LC3 which only swelled 4.6\% (Figure 10c), but noting the fact $\mathrm{KC} 12$ (drier specimen) did have some issues related to the continuity of water phase at the beginning of wetting.

Belfast Clay: Two specimens were compacted at water contents of 17\% (BC1) and 20\% (BC2), which are $7 \%$ and $4 \%$ less than the optimum value. Unfortunately, due to the failure of the air pressure supply to the laboratory, these tests had to be terminated early at a suction of $150 \mathrm{kPa}$ 
(coincidently this happened in both tests). The change in specific water volume is shown in Figure $12 \mathrm{a}$ while the change in radial net stress is shown in Figure $12 \mathrm{~b}$. Figure $12 \mathrm{~b}$ indicates that the maximum horizontal net stress was attained in both cases around suction of $150 \mathrm{kPa}$ with the corresponding values of $K_{o}^{*}$ listed in Table 5. Axial swelling upon saturation is equal to 3.5\% and $2.6 \%$ for specimens $\mathrm{BC} 1$ and $\mathrm{BC} 2$, respectively, at the suction of $150 \mathrm{kPa}$ (Figure 11c).

Ampthill Clay: Two specimens were compacted at water contents of 22\% (AMT1) and 25\% (AMT2), which are $7 \%$ and $4 \%$ less than the optimum value. The change in specific water volume during wetting is shown in Figure 13a while the corresponding change in radial net stress is shown in Figure 13b. The radial net stresses increased substantially at the start of wetting, attaining a maximum value for suctions between $150 \mathrm{kPa}$ and $200 \mathrm{kPa}$ (Figure 13b) but then decreased markedly upon full saturation. The corresponding values of the coefficient $K_{o}^{*}$ are listed in Table 5. Figure 13c shows that, upon saturation, the drier specimen AMT1 swelled $10.3 \%$ while the wetter specimen AMT2 swelled marginally more up to $11.8 \%$. The magnitude of axial swelling was considerably larger for the AMT clay compared to KC, LC and BC, suggesting the presence of expansive minerals and organic materials $(\approx 6 \%)$ in the AMT clay.

Considering all tests, it can be deduced that in most cases a peak value of radial net stress is attained for suctions between $150 \mathrm{kPa}$ and $250 \mathrm{kPa}$. After the peak, the radial net stress decreases as the soil approaches saturation but the magnitude of this reduction depends on compaction effort and overburden pressure. The differences between KC, LC, BC and AMT samples are due to variations in mineralogy, index properties, stress history and particle size distribution. The plasticity indexes of $\mathrm{KC}, \mathrm{LC}, \mathrm{BC}$ and $\mathrm{AMT}$ are 39\%, 44\%, 32\% and 47\%, respectively. Therefore, upon wetting, AMT and LC are expected to show larger axial swelling and greater buildup of stresses under laterally restrained conditions compared to $\mathrm{BC}$ and $\mathrm{KC}$. This is because LC and AMT contain expansive minerals (Table 1) which are not present in significant quantities in $\mathrm{KC}$ and $\mathrm{BC}$. In addition, AMT contains approximately $6 \%$ of organic material which further increases the swelling potential of this material. This hypothesis is supported by Figures 14a and $14 \mathrm{~b}$, which compare the values of the coefficient $K_{o}^{*}$ and the axial swelling for four samples of $\mathrm{KC}, \mathrm{LC}, \mathrm{BC}$ and AMT compacted at the same isotropic pressure of $1200 \mathrm{kPa}$ and water contents 
of $25 \%, 18 \%, 20 \%$ and $25 \%$, respectively. These water contents are between $4-5 \%$ less than the respective optimum values of each material.

In all tests, radial deformations were only impeded during the wetting stage, when suction was reduced from $400 \mathrm{kPa}$ to zero in steps, but not during the initial equalization stage, when suction was brought down from the relatively large value after sampling (Table 2) to 400kPa. If radial deformation had been impeded during the entire wetting process, starting from the state after sampling, the values of the coefficient $K_{0}^{*}$ would have probably been considerably higher than those presented here.

\section{CONCEPTUAL MODELLING}

Figure 15 shows a schematic view of the yield surface (Alonso et al. 1990; Sivakumar et al. 1995) for a compacted clay sample in the $q: \bar{p}: s$ space. Upon application of the isotropic load, the stress state moves to Point A on the $q=0$ plane. The sample is then equalized at a suction of $400 \mathrm{kPa}$ under a constant isotropic load with the stress state moving to Point B still on the $q=0$ plane. At this stage, the $K_{o}^{*}$ condition is invoked and the subsequent wetting path, i.e. $\mathrm{B}_{350^{-}} \mathrm{B}_{300^{-}}$ $\mathrm{B}_{250}-\mathrm{B}_{200}-\mathrm{B}_{150}-\mathrm{B}_{100}-\mathrm{B}_{50}-\mathrm{B}_{0}$ (the subscript indicates the current value of suction), is followed under radially restrained deformation and constant axial net stress (the stress path is therefore contained on a plane with a $\Delta q / \Delta \bar{p}$ slope of $-3 / 2$ ). Due to the relatively high pressures employed during compaction, the B points at higher suctions remain well within the yield locus. Therefore, the sample initially swells axially and undergoes an increase in radial net stress. As suction decreases, the radial net stress increases and this in turn increases the tensile deviator stress taking eventually the soil on the yield locus, with the consequent occurrence of inter-aggregate slippage and plastic collapse (Thom et al., 2007). There is therefore a value of suction for which the radial net stress reaches a maximum (represented by Point $X$ in Figure 15) and, if suction decreases further, the radial net stress and the tensile deviator stress start decreasing as the soil undergoes plastic compression.

\section{Yield domain in $q: \bar{p}: s$ space}


The preceding sections have examined the effect of dry density, compaction water content and overburden pressure on the build-up of radial stresses during wetting under radially restrained conditions. In order to provide a quantitative explanation of the observed behaviour, an attempt is made to establish the yield surface of $\mathrm{KC}$ compacted to $1200 \mathrm{kPa}$ at a water content of $25 \%$. Six specimens were wetted to suctions of zero (KC17 and $\mathrm{KC} 18), 150 \mathrm{kPa}(\mathrm{KC} 20$ and $\mathrm{KC} 21)$ and $300 \mathrm{kPa}(\mathrm{KC} 23$ and $\mathrm{KC} 24)$ under an isotropic stress state $50 \mathrm{kPa}$ and subsequently subjected to further isotropic or radial compression at constant suction (refer to Table 4 for the direction of stress path). Yield stresses were calculated by using a simple graphical construction as suggested by (Casagrande, 1936). These yield stresses are indicated by open circular data points in Figure 16 , together with a qualitative estimate of the constant suction yield loci, to aid interpretation of the test results presented in the next section.

Stress path loading: Three specimens, $\mathrm{KC} 19, \mathrm{KC} 22$ and $\mathrm{KC} 25$, were equalized under an isotropic stress of $50 \mathrm{kPa}$ (see Table 4) at suction of $400 \mathrm{kPa}$. They were then gradually wetted under radially restrained conditions and constant axial net stress $(50 \mathrm{kPa})$ to target suctions of zero, $150 \mathrm{kPa}$, and $300 \mathrm{kPa}$, respectively. After this, suction was maintained constant and the axial stress was increased still under radially restrained conditions. Figures 16a, b and c show the point corresponding to the end of wetting together with the subsequent loading in the $q: \bar{p}$ plane at suctions of zero, 150 and $300 \mathrm{kPa}$, respectively. During $K_{o}^{*}$ wetting to suctions of 150 and $300 \mathrm{kPa}$, the stress path remained inside the initial yield boundary but, during $K_{o}^{*}$ wetting to zero suction, the stress path crossed the initial yield locus. This implies that wetting to zero suction may have induced some plastic straining as the stress path approached saturation. In all three cases, the $K_{o}^{*}$ wetting terminated at a negative value of deviator stress (i.e. $-54 \mathrm{kPa},-60 \mathrm{kPa}$ and $77 \mathrm{kPa}$ for suction values of zero, 150 and $300 \mathrm{kPa}$, respectively) and the subsequent $K_{o}^{*}$ loading increased the deviator stress back to positive values.

The slope of the $K_{o}^{*}$ loading path is very steep at the start but then gradually reduces and approaches a straight line for higher values of deviator stress. At zero suction, the stress path approaches the saturated $K_{o}^{*}$ line soon after the start of loading because the previous wetting 
stage had produced plastic deformation. At the other two values of suction, the behaviour is very similar to that of an over-consolidated saturated soil. Interestingly, the slopes of the $K_{o}^{*}$ lines at different suctions are reasonably parallel, though the intercepts depend on suction and become smaller as suction reduces to zero. At a suction value of zero, one would expect the intercept to be zero, though the observed behaviour indicates that this is not true, probably because of the aggregated structure of the compacted soil even at the saturated state (Thom et al. 2007).

Figure 17 shows the wetting path of specimens $\mathrm{KC} 11, \mathrm{KC} 8, \mathrm{KC} 5$ and $\mathrm{KC} 14$ (regarded as heavily engineered, engineered, un-engineered and poorly engineered) in the $q: s$ and $s: \bar{p}$ planes. All specimens were compacted at the same water content of $25 \%$ but were subjected to different compaction efforts. The specimens were wetted under radially restrained conditions with a constant overburden pressure of 50kPa. Also included in Figure 17 are the yield loci for KC8 (engineered specimen). Naturally, these yield loci are only relevant to KC8 and are not applicable to $\mathrm{KC} 5, \mathrm{KC} 11$ and $\mathrm{KC} 14$ as these specimens have different initial dry densities and therefore different yield loci. As per $\mathrm{KC} 8$, the wetting path is initially well within the yield domain and only approaches yielding when suction is reduced to about 50kPa (Figure 17b), confirming the earlier discussion on the development of lateral stresses during wetting.

\section{CONCLUSION}

Compacted fills made of clay are becoming more common in construction practice. Wetting of compacted fills around buried rigid structures or behind retaining walls, can lead to the development of excessive stresses inside the soil. The magnitude of these stresses is influenced by several factors which include: dry density, overburden pressure, stress history, compaction water-content and clay mineralogy. This article examined these factors through a body of laboratory investigations and the main conclusions are:

- Compacted clay fills are unsaturated at the time of placement and the value of initial suction can vary significantly being largely influenced by compaction water content.

- Post-compaction wetting (i.e. saturation) leads to a gradual reduction in suction under constant overburden pressure. If the deformation of the compacted material is restricted, 
this wetting process may cause the development of excessive stresses inside the soil. This can lead to a significant increase in $K_{o}^{*}$ values (the ratio between horizontal net stress and vertical stress).

- Continued wetting of the specimens resulted in some relaxation of lateral stresses, particularly when approaching a near-saturated state.

- The magnitude of wetting-induced stresses (and therefore the value of $K_{o}^{*}$ ) was significantly affected by the initial dry density, compaction water content, overburden pressure, stress history and clay mineralogy. The most significant development of stress was observed in the case of Ampthill clay which contained a certain percentage of expansive minerals and a marginal organic content.

- During laboratory tests, specimens were restrained from deforming radially, though they were allowed to deform in the axial direction. The axial expansions of the specimens were again influenced by the above mentioned factors. In the case of Ampthill clay, the axial expansion was significant and as high as $12 \%$.

- The observed behaviour was explained using a conceptual constitutive model for the soil. In a limited number of tests on Kaolin clay the value of $K_{o}^{*}$ was measured under axial loading at constant suction and radially restrained deformation. Test results showed that the slope of the $K_{o}^{*}$ line was unaffected by the suction value.

- The above conceptual model allows to understand the response of compacted fine grained fills to variations in overburden pressure, wetting, stress history and initial density/soil suction. This model can therefore be used by designers to understand the impact of long term moisture changes within the fill and the associated changes of the coefficient of earth pressure at rest.

\section{REFERENCES}

Airò Farulla, C., Rosone, M. (2012). Microstructure Characteristics of Unsaturated Compacted Scaly Clay. In Proceedings of 2nd European Conference on Unsaturated Soils (Unsaturated Soils: Research and Applications): 123-130. Naples, Italy, 20-22 June 2012, Springer, ISBN: 978-3-642-31342-4 
Alonso, E. E., Gens, A., and Josa, A. (1990) A constitutive model for partially saturated soils. Géotechnique, 40(3), 405-430.

Boyd, J. L. and Sivakumar, V. (2011) Experimental observations of the stress regime in unsaturated compacted clay when laterally confined. Géotechnique, 61(4), 346-363.

Brown, J and Sivakumar, V (2008) The changes in stress regime during wetting of unsaturated compacted clays when laterally confined. In: Unsaturated Soils Advances in GeoEngineering. CRC Press, Balkema, pp. 361-367.

Carder, D. R. (1988) Earth pressures on retaining walls and abutments. Ground Engineering, 21(5), 7-10.

Casagrande, A. (1936). The determination of the pre-consolidation load and its practical significance, Proceedings, $1^{\text {st }}$ International Conference on Soil Mechanics, Cambridge, Mass, Vol. 3.

Charles, J. A. (1993) Building on fill: Geotechnical aspects. The Building Research Establishment, Watford, United Kingdom.

Chen, F. H. (1987) Lateral expansion pressure on basement walls. Proc. of the $6^{\text {th }}$ Int. Conf. on Expansive Soils, 1, 55-59.

Clayton, C.R.I., Symons, J.C. and Hiedra. C. (1991). The pressure of clay backfill against retaining structures. Canadian Geotechnical Journal, Vol. 28, No. 2 pp 282-297

Cui, Y. J., and Delage, P. (1996) Yielding and plastic behaviour of an unsaturated compacted silt. Geotechnique, 46(2), 291-311.

Delage, P. and Graham, J. (1995) Mechanical behaviour of unsaturated soils: Understanding the behaviour of unsaturated soils requires reliable conceptual models. Proc. of the $1^{\text {st }}$ Int. Conf. on Unsaturated Soils, Paris, France, 3, 1223-1256.

Delage, P., Audigiuer, M., Cui, Y. J., and Howat, M. D. (1996) Microstructure of a compacted silt. Canadian Geotechnical Journal, 33(1), 150-158.

Hilf, J. N. (1956) An investigation of pore water pressure in compacted cohesive soils. Technical Memorandum 654, U.S. Department of Interior Bureau of Reclamation, Denver.

Highways Agency, Scottish Development Department, The Welsh Office, and The Department for the Environment for Northern Ireland (1995) Earthworks design and preparation of contract documents, HA 44/91; Design manual for roads and bridges, 4, Geotechnical drainage, London. 
Highways Agency, Scottish Development Department, The Welsh Office, and The Department for the Environment for Northern Ireland (2004) Manual of contract documents for highways works MCHW1; Specification for highways works: Series 600, Earthworks, London.

Lloret, A., Villar, M. V., Sanchez, M., Gens, A., Pintado, X., and Alonso, E. E. (2003) Mechanical behaviour of heavily compacted bentonite under high suction changes. Géotechnique, 53(1), 27-40.

Lu, N., and Likos, W. J. (2004) Unsaturated Soil Mechanics, John Wiley and Sons, Inc.

Maswoswe (1985) Stress path for a compacted soil during collapse due to wetting. PhD Thesis, Imperial College London.

Mawditt, J.M. (1989). Discussion on Symons and Murray, Proceedings of Institution of civil Engineers, Part 1, 89. pp 243-247

Monroy, R., Zdravkovic, L., \& Ridley, A. (2010). Evolution of microstructure in compacted London clay during wetting and loading. Geotechnique 60, 105-119.

Romero, E., Della Vecchia, G., Jommi, C. (2011). An insight into the water retention properties of compacted clayey soils. Géotechnique 61:(4), 313-328.

Schanz, T., Tripathy, S. (2009). Swelling pressure of a divalent-rich bentonite: Diffuse double-layer theory revisited. Water Resour. Res. 45(5), W00C12.

Sivakumar, V., and Wheeler, S. J. (2000) Influence of compaction procedure on the mechanical behaviour of an unsaturated compacted clay, Part 1: Wetting and isotropic compression. Géotechnique, 50(4), 359-368.

Sivakumar, V., Sivakumar, R., Brown, J., Murray, E.J., and Mackinnnon, P. (2010a) Constitutive modelling of unsaturated kaolin (with isotropic and anisotropic stress history). Part 1: Wetting and compression behaviour. Geotechnique, Vol 60No.8, pp 581-594.

Symons, I.F., Clayton, C.R.I, and Darley, P. 1989. Earth pressure against an experimental retaining wall backfilled with heavy clays. Transport and Research laboratory, No.192, Crowthome, Berkshire

Thom, R., Sivakumar, V., Sivakumar, R., Murray, E. J., and Mackinnon, P. (2007) Technical Note: Pore size distribution of unsaturated compacted kaolin: the initial states and final states following saturation. Géotechnique, 57(7), 469-474. 
Toll, D. G. (1999) A data acquisition and control system for geotechnical testing. In Computing Developments in Civil and Structural Engineering (eds. B. Kumar and B. H. V. Topping) Civil-Comp Press, Edinburgh, 237-242.

Wheeler, S. J. and Sivakumar, V. (1995) An elasto-plastic critical state framework for unsaturated soil. Géotechnique, 45(1), 35-53. 
Table 1: Physical characteristics of clays

\begin{tabular}{|c|l|c|c|c|c|c|}
\hline Clay type & \multicolumn{1}{|c|}{ Clay minerals } & $\begin{array}{c}\text { Percentage } \\
\text { clay size } \\
\text { fraction (\%) }\end{array}$ & $\begin{array}{c}\text { Liquid } \\
\text { Limit } \\
(\%)\end{array}$ & $\begin{array}{c}\text { Plastic } \\
\text { Limit } \\
(\%)\end{array}$ & $\begin{array}{c}\text { Plasticity } \\
\text { Index (\%) }\end{array}$ & $\begin{array}{c}\text { Optimum } \\
\text { moisture } \\
\text { content (\%) }\end{array}$ \\
\hline $\begin{array}{c}\text { Kaolin Clay } \\
\text { (KC) }\end{array}$ & $\begin{array}{l}\text { Kaolinite (96.5\%) } \\
\text { Muscovite (2.2\%) } \\
\text { Quartz (1.4\%) }\end{array}$ & 80 & 70 & 31 & 39 & 30 \\
\hline $\begin{array}{c}\text { London Clay } \\
\text { (LC) }\end{array}$ & $\begin{array}{l}\text { Feldspar (2\%) } \\
\text { Illite (22.5\%) } \\
\text { Kaolinite (7.1\%) } \\
\text { Montmorillonite (2.3\%) } \\
\text { Chlorite (5.4\%) } \\
\text { Quartz (49.7\%) } \\
\text { Smectite (3.1\%) }\end{array}$ & 40 & 71 & 27 & 44 & 23 \\
\hline $\begin{array}{c}\text { Quartz (22.0\%) } \\
\text { Dolomite (12.7\%) } \\
\text { Muscovite (28.3\%) } \\
\text { Chlorite (8.7\%) } \\
\text { Calcite (4.1\%) } \\
\text { Kaolinite (12.1\%) } \\
\text { Montmorillonite (2\%) }\end{array}$ & 58 & 55 & 23 & 32 & 24 \\
\hline $\begin{array}{l}\text { Quartz (40.5\%) } \\
\text { Pyrite (2.5\%) } \\
\text { Muscovite (31.5\%) } \\
\text { Chlorite (5.5\%) } \\
\text { Calcite (3.5\%) } \\
\text { Feldspar (1.5\%) } \\
\text { Kaolinite (15.1\%) }\end{array}$ & 57 & 77 & 30 & 47 & 29 \\
\hline Ampthill Clay \\
(AM)
\end{tabular}




\begin{tabular}{|c|c|c|c|c|}
\hline $\begin{array}{l}\text { Clay } \\
\text { type }\end{array}$ & Fill Name & Compaction water content $(\%)$ & $\begin{array}{l}\text { Compaction } \\
\text { pressure }(\mathrm{kPa})\end{array}$ & $\begin{array}{l}\text { Suction } \\
(\mathrm{kPa})\end{array}$ \\
\hline \multirow{6}{*}{$\mathrm{KC}$} & Un-engineered & $25(\mathrm{KC} 14)$ & 400 & 1535 \\
\hline & Poorly engineered & $25(\mathrm{KC} 5)$ & 800 & 1379 \\
\hline & \multirow{3}{*}{ Engineered } & $22(\mathrm{KC} 12)$ & \multirow{3}{*}{1200} & 1440 \\
\hline & & $25(\mathrm{KC} 7,89,15,16)$ & & 1294 \\
\hline & & $28(\mathrm{KC} 13)$ & & 1088 \\
\hline & Heavily engineered & 25(KC11) & 1600 & 1268 \\
\hline \multirow{2}{*}{$\mathrm{LC}$} & \multirow{2}{*}{ Heavily engineered } & 15 (LC1) & \multirow{2}{*}{1200} & 1593 \\
\hline & & 18(LC3) & & 1306 \\
\hline \multirow{2}{*}{$\mathrm{BC}$} & \multirow{2}{*}{ Heavily engineered } & $17(\mathrm{BC} 1)$ & \multirow{2}{*}{1200} & 1926 \\
\hline & & $20(\mathrm{BC} 2)$ & & 1308 \\
\hline \multirow{2}{*}{ AMT } & \multirow{2}{*}{ Heavily engineered } & $22(\mathrm{AC} 1)$ & \multirow{2}{*}{1200} & 1527 \\
\hline & & 25(AC2) & & 1015 \\
\hline
\end{tabular}




\begin{tabular}{|c|c|c|c|c|c|c|c|}
\hline \multicolumn{8}{|c|}{ Table 3: Initial characteristics of specimens } \\
\hline Sample & $\begin{array}{c}w \\
(\%)\end{array}$ & $\begin{array}{c}\rho_{d} \\
\left(\mathrm{Mg} / \mathrm{m}^{3}\right)\end{array}$ & $\begin{array}{l}S_{r} \\
(\%)\end{array}$ & $\begin{array}{c}\overline{\overline{\sigma_{v}}} \\
(\mathrm{kPa})\end{array}$ & $v$ & $v_{w}$ & Testing method \\
\hline \multicolumn{8}{|c|}{ Kaolin Clay (KC) } \\
\hline KC5 & 25 & 1.25 & 59.8 & 50 & 2.115 & 1.666 & Radially restrained \\
\hline KC7 & 25 & 1.32 & 66.6 & 25 & 2.020 & 1.680 & Radially restrained \\
\hline $\mathrm{KC} 8$ & 25 & 1.32 & 67.5 & 50 & 2.011 & 1.679 & Radially restrained \\
\hline $\mathrm{KC} 9$ & 25 & 1.31 & 65.1 & 100 & 2.025 & 1.667 & Radially restrained \\
\hline $\mathrm{KC} 11$ & 25 & 1.36 & 70.0 & 50 & 1.942 & 1.659 & Radially restrained \\
\hline $\mathrm{KC} 12$ & 22 & 1.26 & 56.2 & 50 & 2.065 & 1.598 & Radially restrained \\
\hline $\mathrm{KC} 13$ & 28 & 1.40 & 80.6 & 50 & 1.942 & 1.759 & Radially restrained \\
\hline KC14 & 25 & 1.19 & 54.8 & 50 & 2.233 & 1.676 & Radially restrained \\
\hline $\mathrm{KC} 15$ & 25 & 1.31 & 65.5 & 100 & 2.030 & 1.674 & No radial restrain \\
\hline $\mathrm{KC} 16$ & 25 & 1.31 & 65.5 & 50 & 2.030 & 1.674 & No radial restrain \\
\hline \multicolumn{8}{|c|}{ London Clay (LC) } \\
\hline LC1 & 15 & 1.53 & 66.4 & 50 & 1.586 & 1.389 & Radially restrained \\
\hline LC3 & 18 & 1.56 & 77.2 & 50 & 1.584 & 1.451 & Radially restrained \\
\hline \multicolumn{8}{|c|}{ Belfast Clay (BC) } \\
\hline $\mathrm{BC} 1$ & 17 & 1.49 & 67.2 & 50 & 1.666 & 1.448 & Radially restrained \\
\hline $\mathrm{BC} 2$ & 20 & 1.62 & 98.4 & 50 & 1.596 & 1.586 & Radially restrained \\
\hline \multicolumn{8}{|c|}{ Ampthill Clay (AMT) } \\
\hline AMT1 & 22 & 1.47 & 75.0 & 50 & 1.786 & 1.631 & Radially restrained \\
\hline AMT2 & 25 & 1.32 & 33.9 & 50 & 1.748 & 1.677 & Radially restrained \\
\hline
\end{tabular}




\begin{tabular}{|c|c|c|c|c|}
\hline \multicolumn{7}{|c|}{ Table 4: Stress path and $K_{0}^{*}$ loading tests at different suctions } \\
\hline Sample & $w(\%)$ & $\begin{array}{c}\rho_{d} \\
\left(\mathrm{Mg} / \mathrm{m}^{3}\right)\end{array}$ & $\begin{array}{c}\text { Suction } \\
\mathrm{kPa}\end{array}$ & Loading path \\
\hline $\mathrm{KC} 17$ & 25 & 1.31 & 0 & Isotropic compression* \\
\hline $\mathrm{KC} 18$ & 25 & 1.30 & 0 & $\Delta q / \Delta \bar{p}=-\infty *$ \\
\hline $\mathrm{KC} 19$ & 25 & 1.29 & 0 & $K_{0}^{*}$ loading** \\
\hline $\mathrm{KC} 20$ & 25 & 1.30 & 150 & Isotropic compression* \\
\hline $\mathrm{KC} 21$ & 25 & 1.25 & 150 & $\Delta q / \Delta \bar{p}=-3 / 2^{*}$ \\
\hline $\mathrm{KC} 22$ & 25 & 1.26 & 150 & $K_{0}^{*}$ loading** \\
\hline $\mathrm{KC} 23$ & 25 & 1.32 & 300 & Isotropic compression* \\
\hline $\mathrm{KC} 24$ & 25 & 1.32 & 300 & $\Delta q / \Delta \bar{p}=-3 / 2^{*}$ \\
\hline $\mathrm{KC} 25$ & 25 & 1.32 & 300 & $K_{0}^{*}$ loading** \\
\hline
\end{tabular}

* Specimens were equalized to the target suction without restraining radial strains

** Specimens were equalized to the target suction under radially restrained conditions 


\begin{tabular}{|c|c|c|c|c|c|c|}
\hline \multicolumn{7}{|c|}{ Table 5: $K_{0}^{*}$ values upon wetting } \\
\hline Sample & $\begin{array}{c}w \\
(\%)\end{array}$ & $\begin{array}{c}\rho_{d} \\
\left(\mathrm{M} / \mathrm{cm}^{3}\right)\end{array}$ & $\begin{array}{c}\overline{\sigma_{v}} \\
(\mathrm{kPa})\end{array}$ & $v_{w}$ & $\begin{array}{c}\text { Maximum } K_{o}^{*} \\
(\text { suction } \mathrm{kPa})\end{array}$ & $\begin{array}{c}\text { Saturation } \\
K_{0}^{*}\end{array}$ \\
\hline \multicolumn{7}{|c|}{ KC } \\
\hline $\mathrm{KC} 5$ & 25 & 1.25 & 50 & 1.666 & $1.82(200-300)$ & 1.60 \\
\hline $\mathrm{KC} 7$ & 25 & 1.32 & 25 & 1.680 & $3.60(200)$ & 2.80 \\
\hline $\mathrm{KC} 8$ & 25 & 1.32 & 50 & 1.679 & $1.97(100-200)$ & 1.80 \\
\hline KC9 & 25 & 1.31 & 100 & 1.667 & $1.44(0-200)$ & 1.42 \\
\hline KC11 & 25 & 1.36 & 50 & 1.659 & $2.74(200-250)$ & 2.20 \\
\hline $\mathrm{KC} 12$ & 22 & 1.26 & 50 & 1.598 & $2.00(200-250)$ & 1.80 \\
\hline $\mathrm{KC} 13$ & 28 & 1.40 & 50 & 1.759 & $2.40(150-200)$ & 2.00 \\
\hline $\mathrm{KC} 14$ & 25 & 1.19 & 50 & 1.676 & $1.38(250-300)$ & 1.14 \\
\hline \multicolumn{7}{|c|}{ LC } \\
\hline LC1 & 15 & 1.53 & 50 & 1.389 & $3.30(100-200)$ & 2.50 \\
\hline LC3 & 18 & 1.56 & 50 & 1.451 & $3.60(100-200)$ & 3.42 \\
\hline \multicolumn{7}{|c|}{ BC } \\
\hline $\mathrm{BC} 1$ & 17 & 1.49 & 50 & 1.448 & $2.60(150)$ & \\
\hline $\mathrm{BC} 2$ & 20 & 1.62 & 50 & 1.586 & $3.16(150)$ & \\
\hline \multicolumn{7}{|c|}{ AMT } \\
\hline AMT1 & 22 & 1.47 & 50 & 1.631 & $3.50(150-200)$ & 2.8 \\
\hline AMT2 & 25 & 1.32 & 50 & 1.677 & $4.20(100-150)$ & 3.5 \\
\hline
\end{tabular}




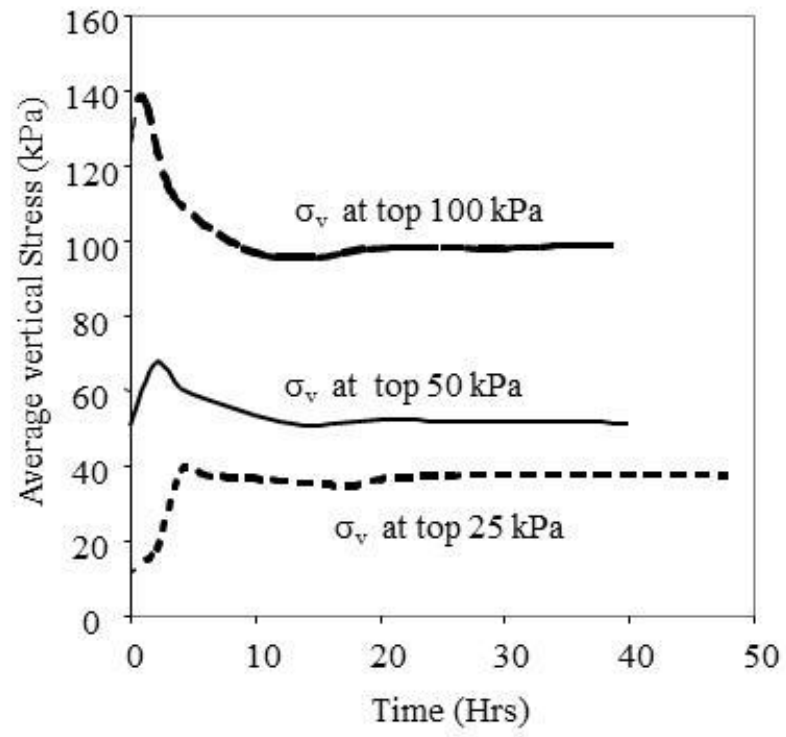

Figure 1 Wetting of compacted kaolin in Rowe Cell under various vertical pressures 


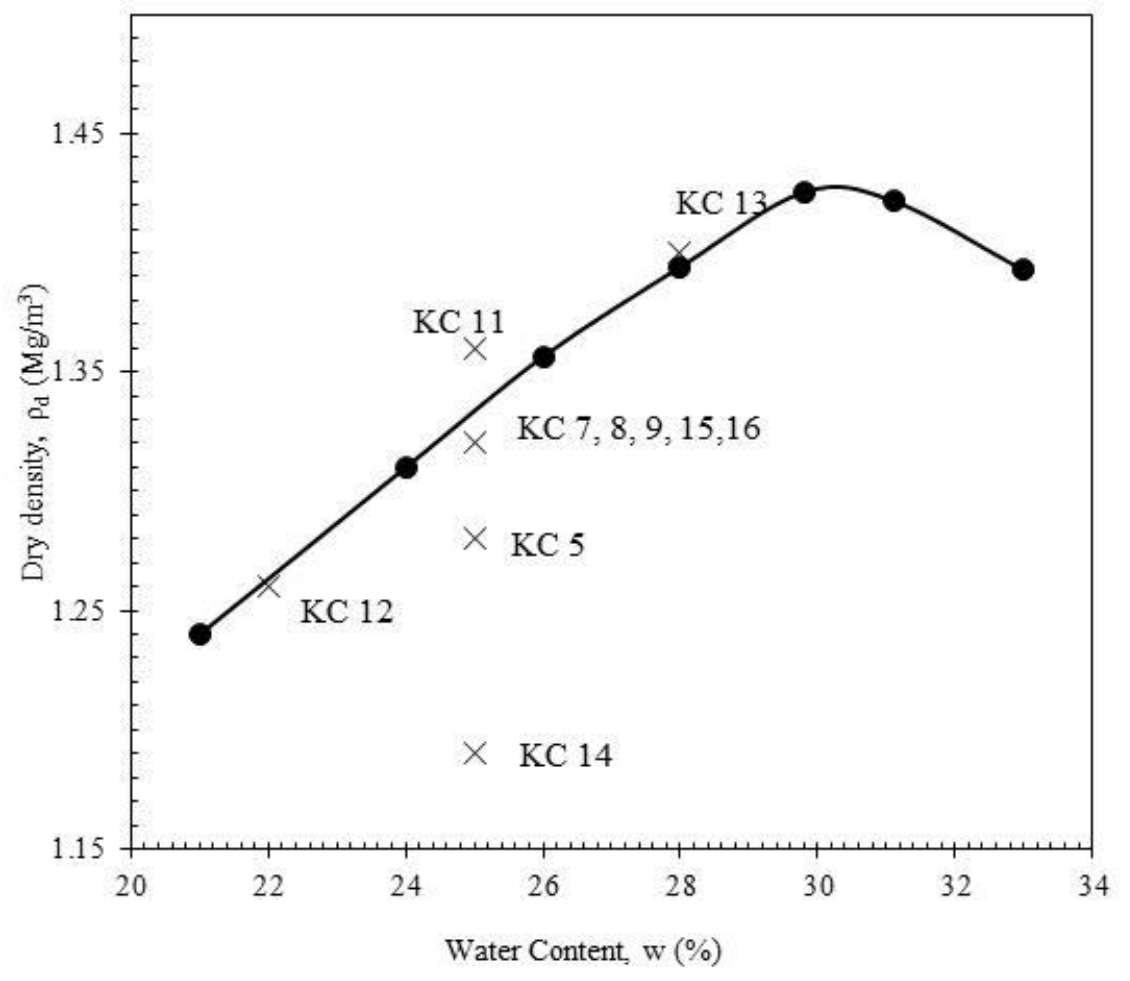

Figure 2 Proctor compaction curve: kaolin clay 

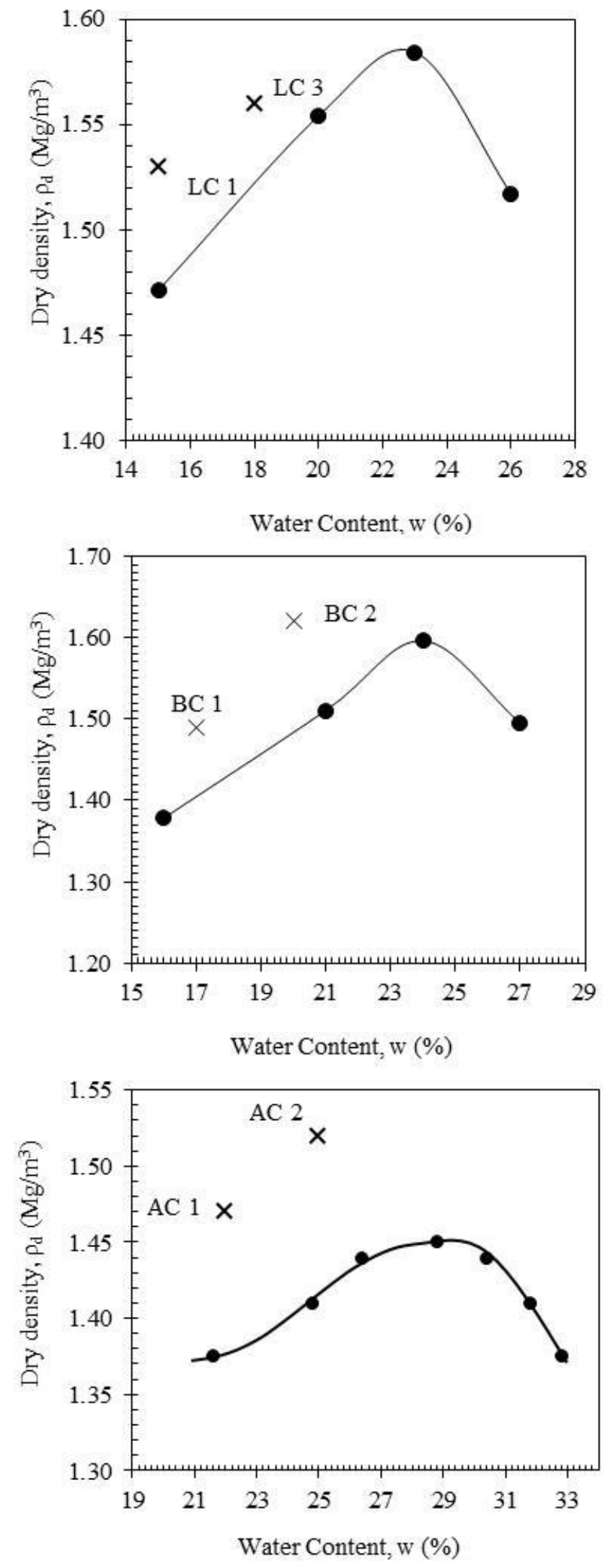

Figure 3 Proctor compaction: London Clay, Belfast Clay and Ampthil Clay 


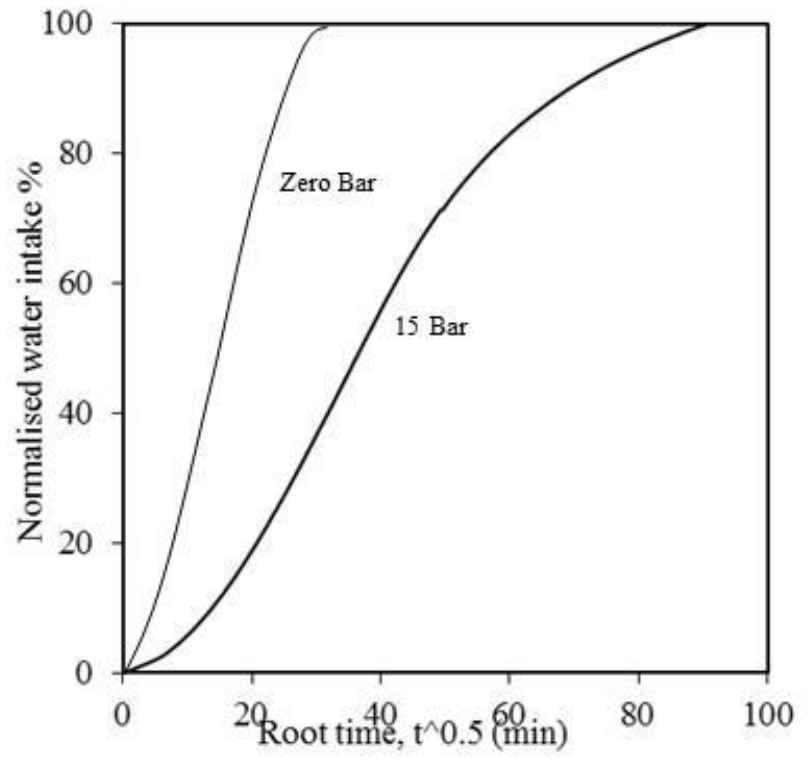

(a) Effect of air entry ceramic filter on the water flow into the sample

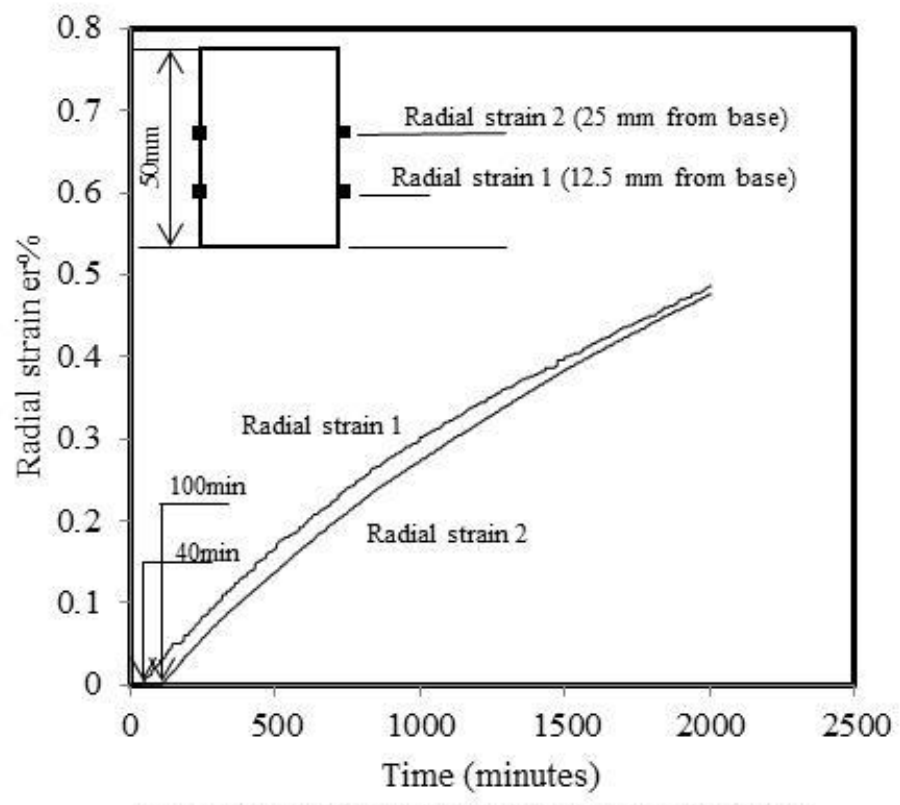

(b) Radial strains measured at two locations along the height

Figure 4 Effects of ceramic filter on saturation of unsaturated soils and radial strain measurements at two locations along the height 


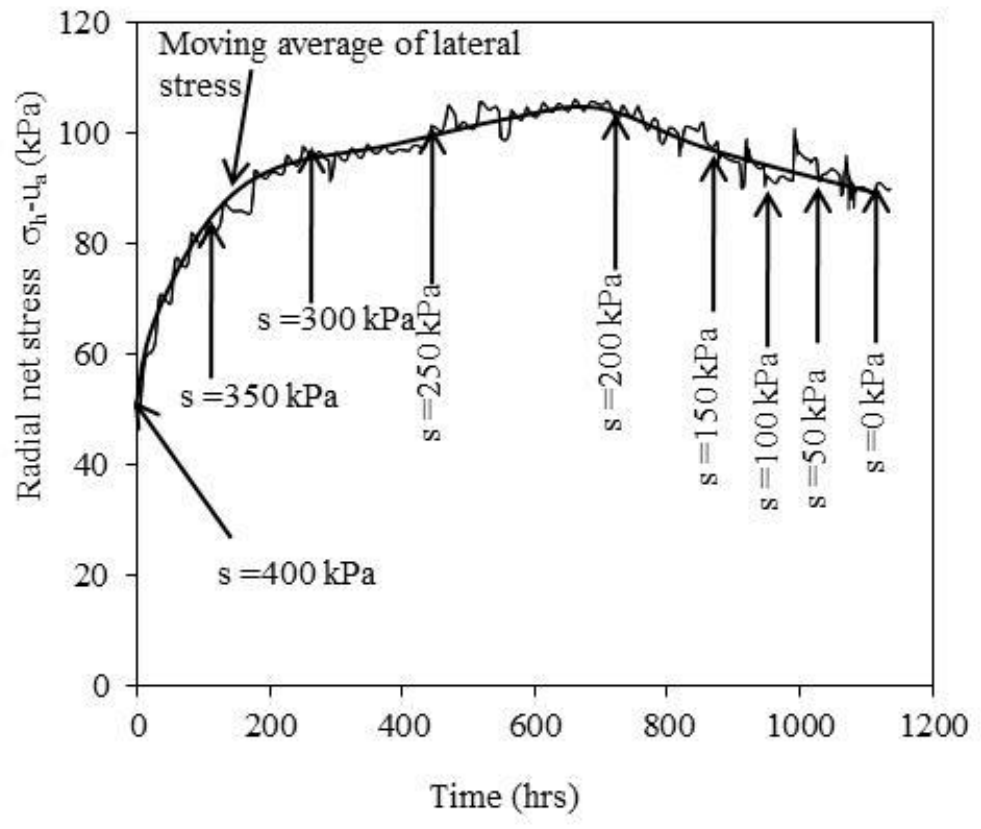

Figure 5 Variation of radial net stress during decrease in suction $50 \mathrm{kPa}$ step 


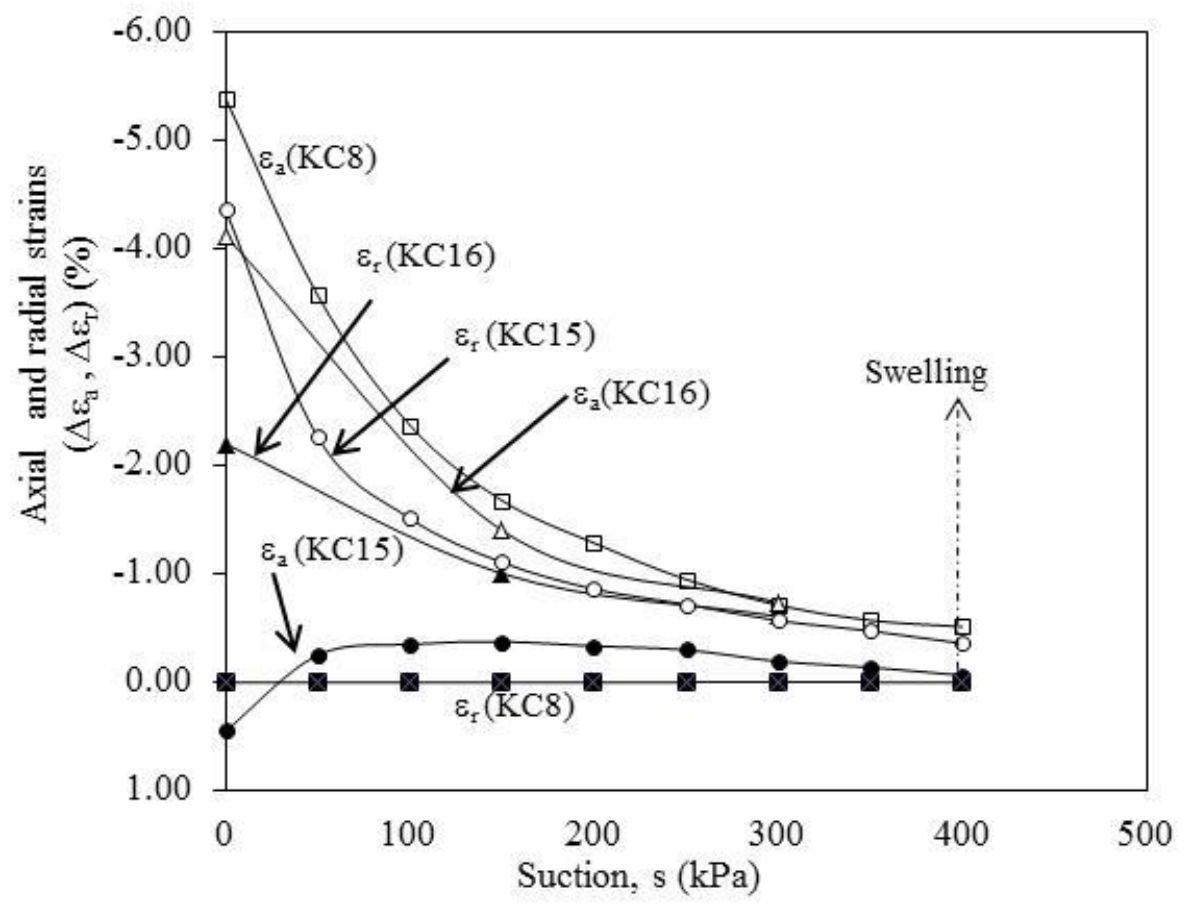

Figure 6 Swelling/collapse of compacted kaolin 


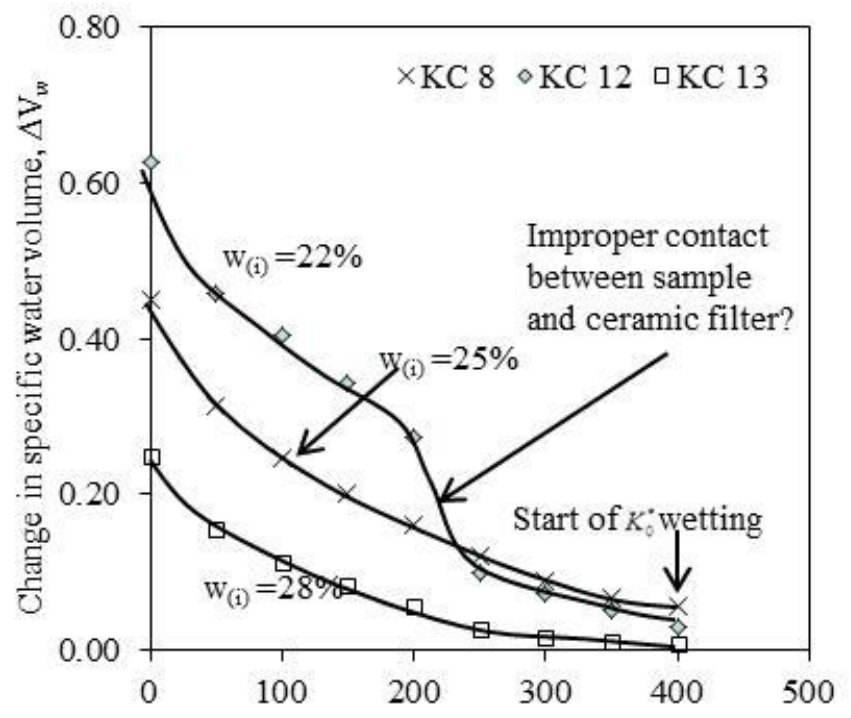

(a) Water-intake

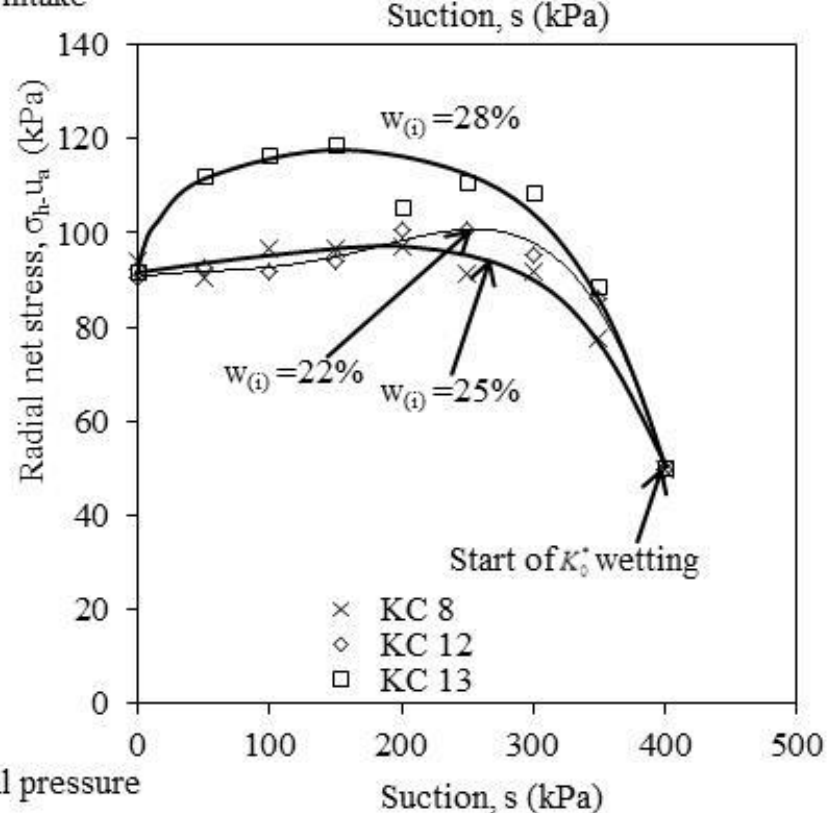

(b) Lateral pressure Suction, $\mathrm{s}(\mathrm{kPa})$

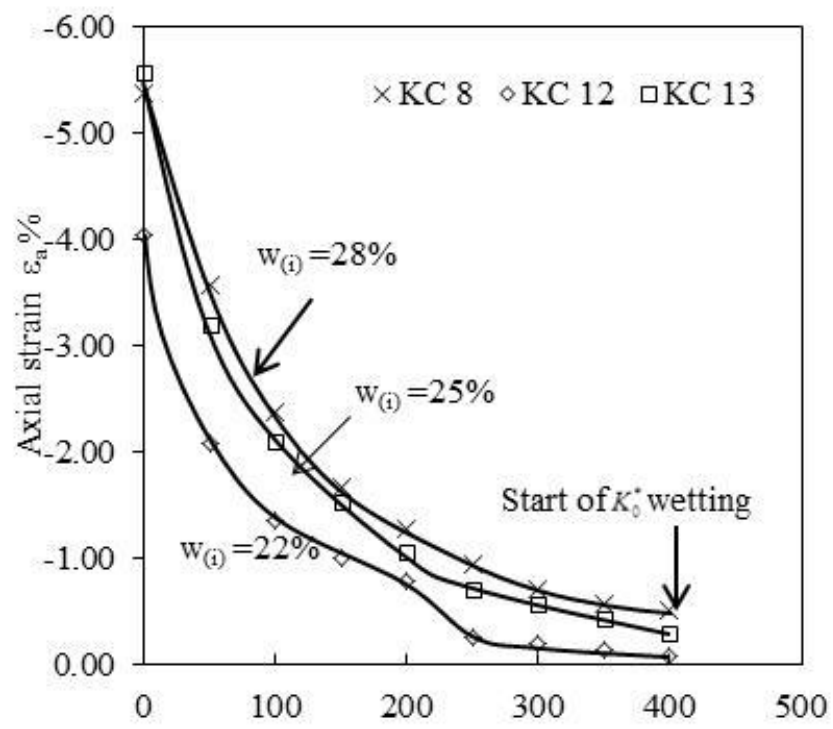

(c) Axial expansion

Suction, $\mathrm{s}(\mathrm{kPa})$

Figure 7 Effect of compaction water content on water intake, radial net stress and axial swelling during $K_{0}^{*}$ wetting (KC) 


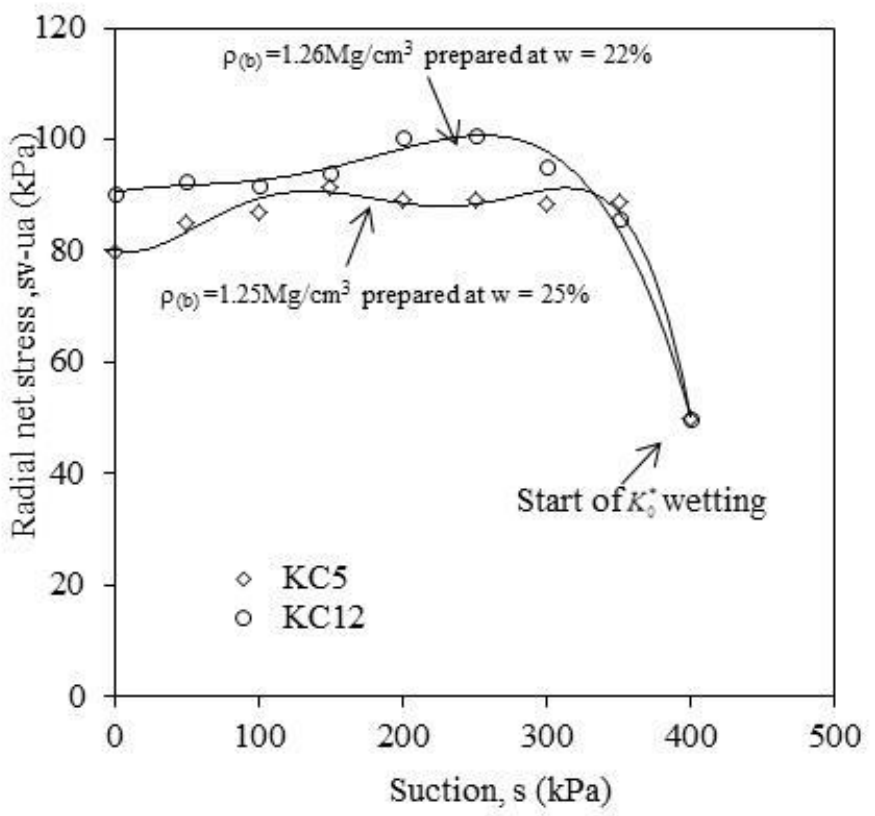

Figure 8 Effect of compaction water content for a given initial dry density 


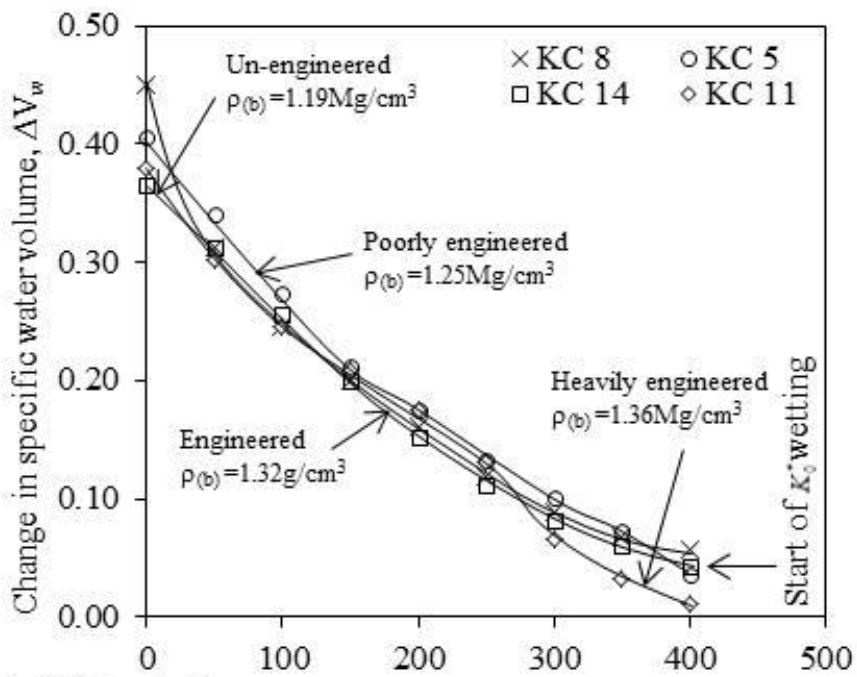

(a) Water-intake Suction, $\mathrm{s}(\mathrm{kPa})$

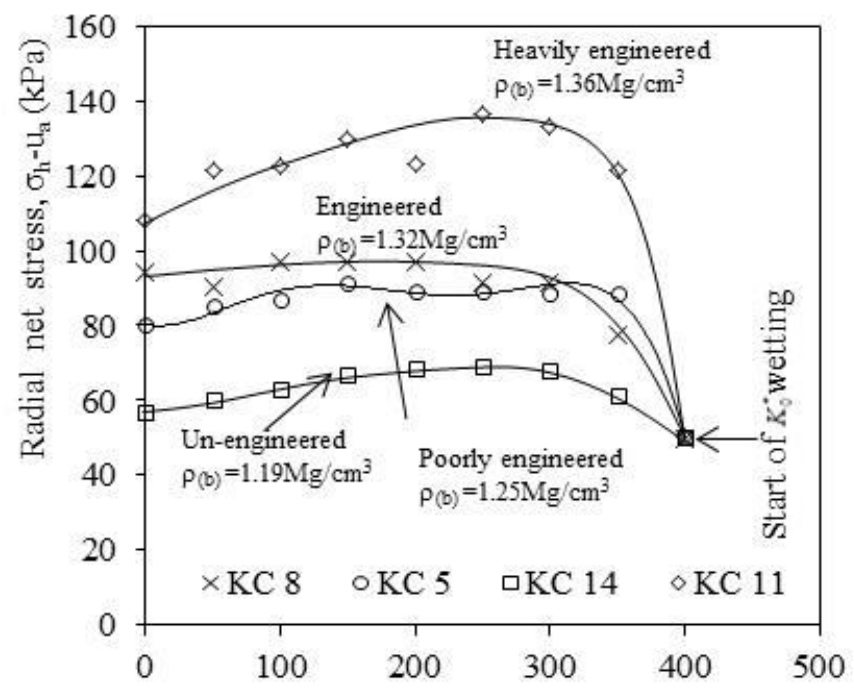

(b) Lateral pressure Suction, $\mathrm{s}(\mathrm{kPa})$

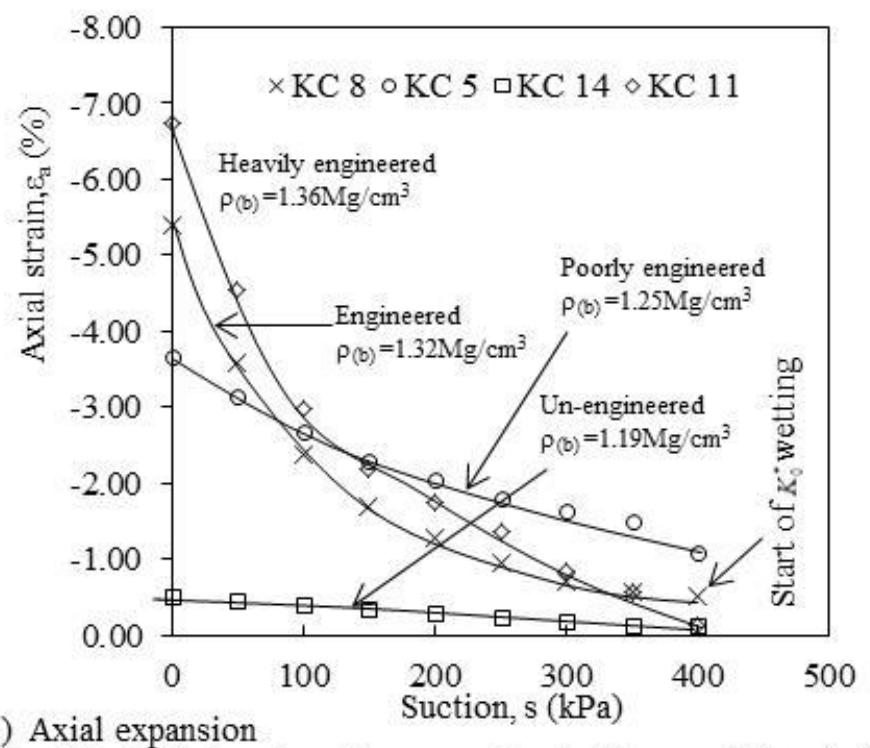

(c) Axial expansion

Figure 9 Effect of initial dry density on water intake, radial net stress and axial swelling during $K_{\circ}^{*}$ wetting (KC) 


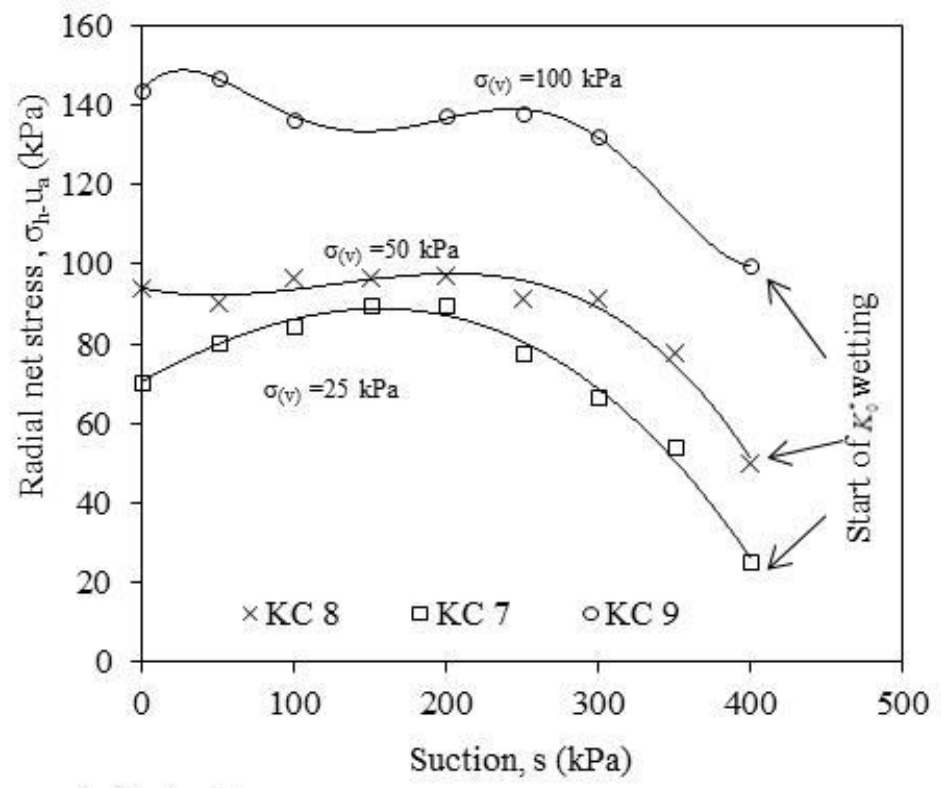

(a) Lateral pressure

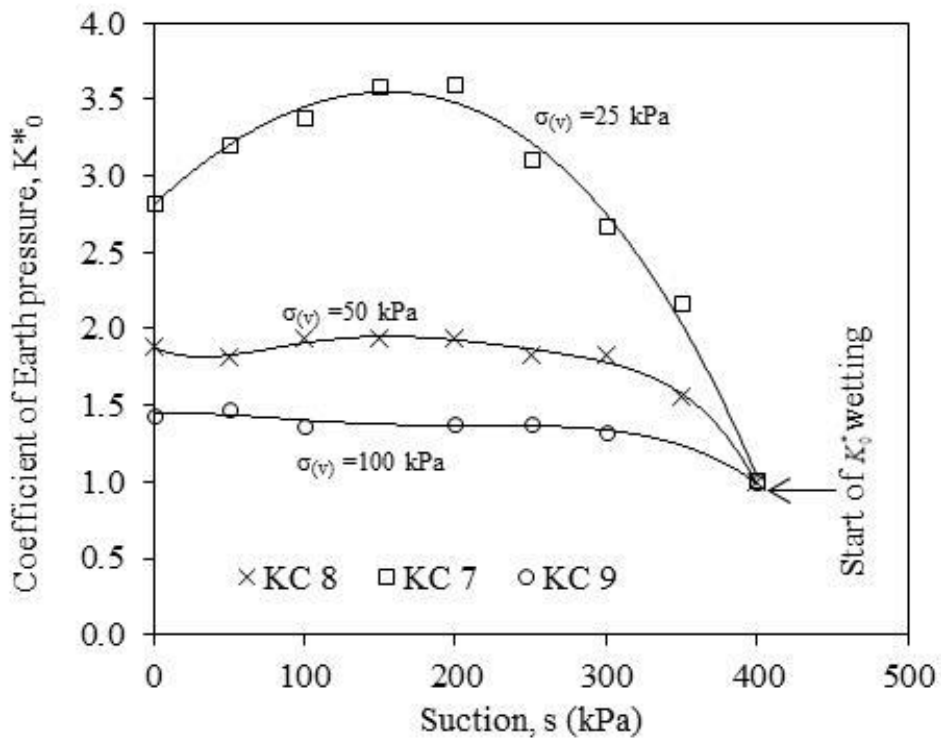

(b) $\mathrm{K}_{0}{ }^{*}$

Figure 10 Effect of overburden pressure on radial net stress and axial swelling during $K_{0}^{*}$ wetting $(\mathrm{KC})$ 


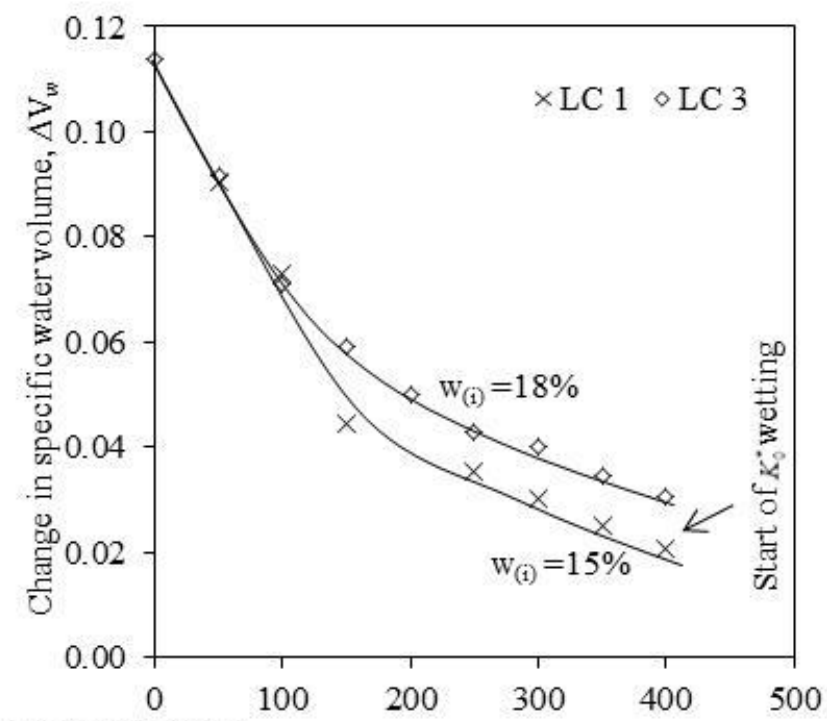

(a) Water-intake

Suction, $\mathrm{s}(\mathrm{kPa})$

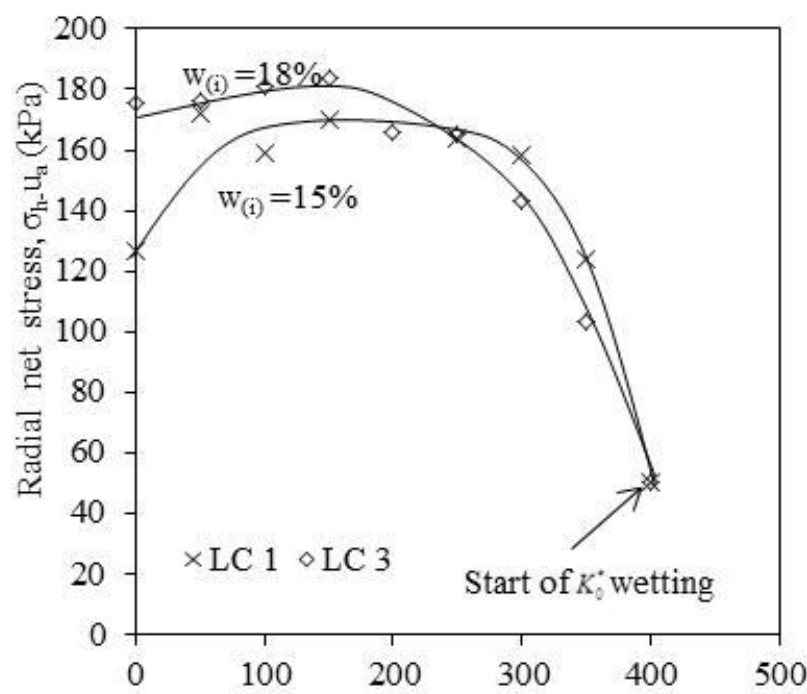

(b) Lateral pressure

Suction, $\mathrm{s}(\mathrm{kPa})$

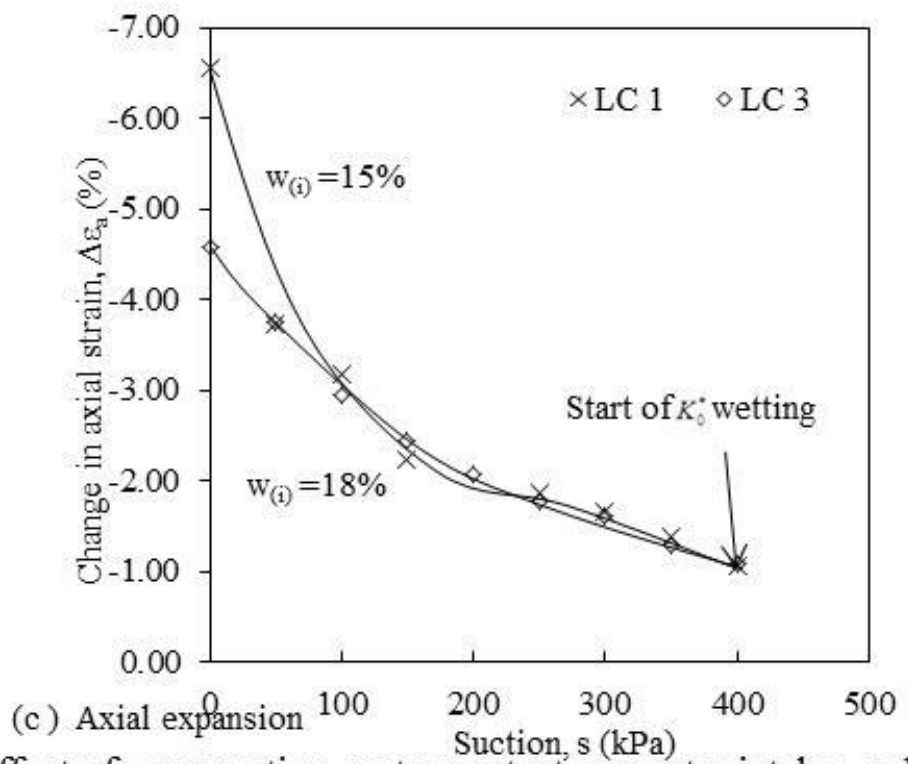

Figure 11 Effect of compaction water content on water intake, radial net stress and axial swelling during $K_{0}^{*}$ wetting (LC) 


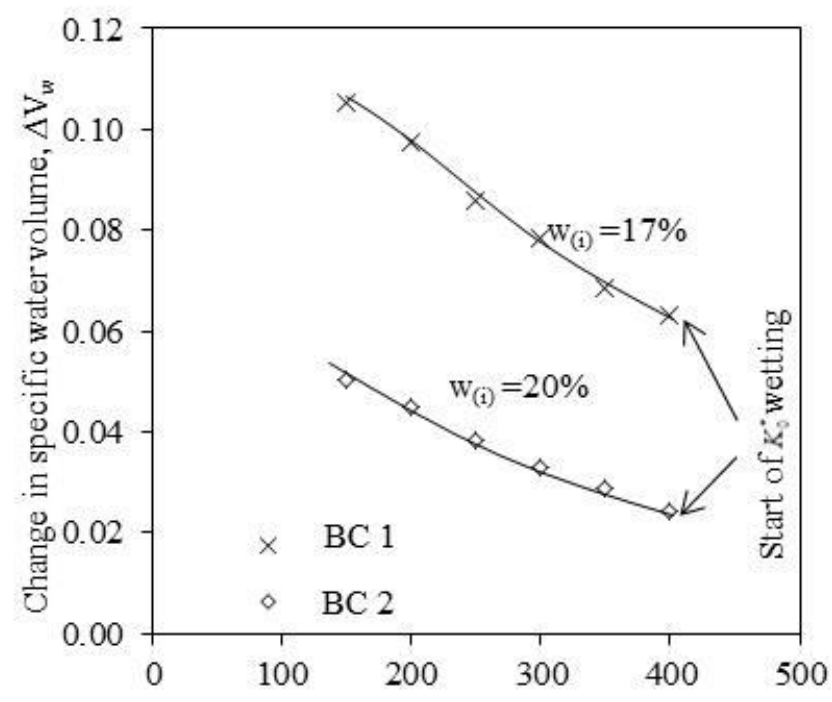

(a) Water-intake Suction, $\mathrm{s}(\mathrm{kPa})$
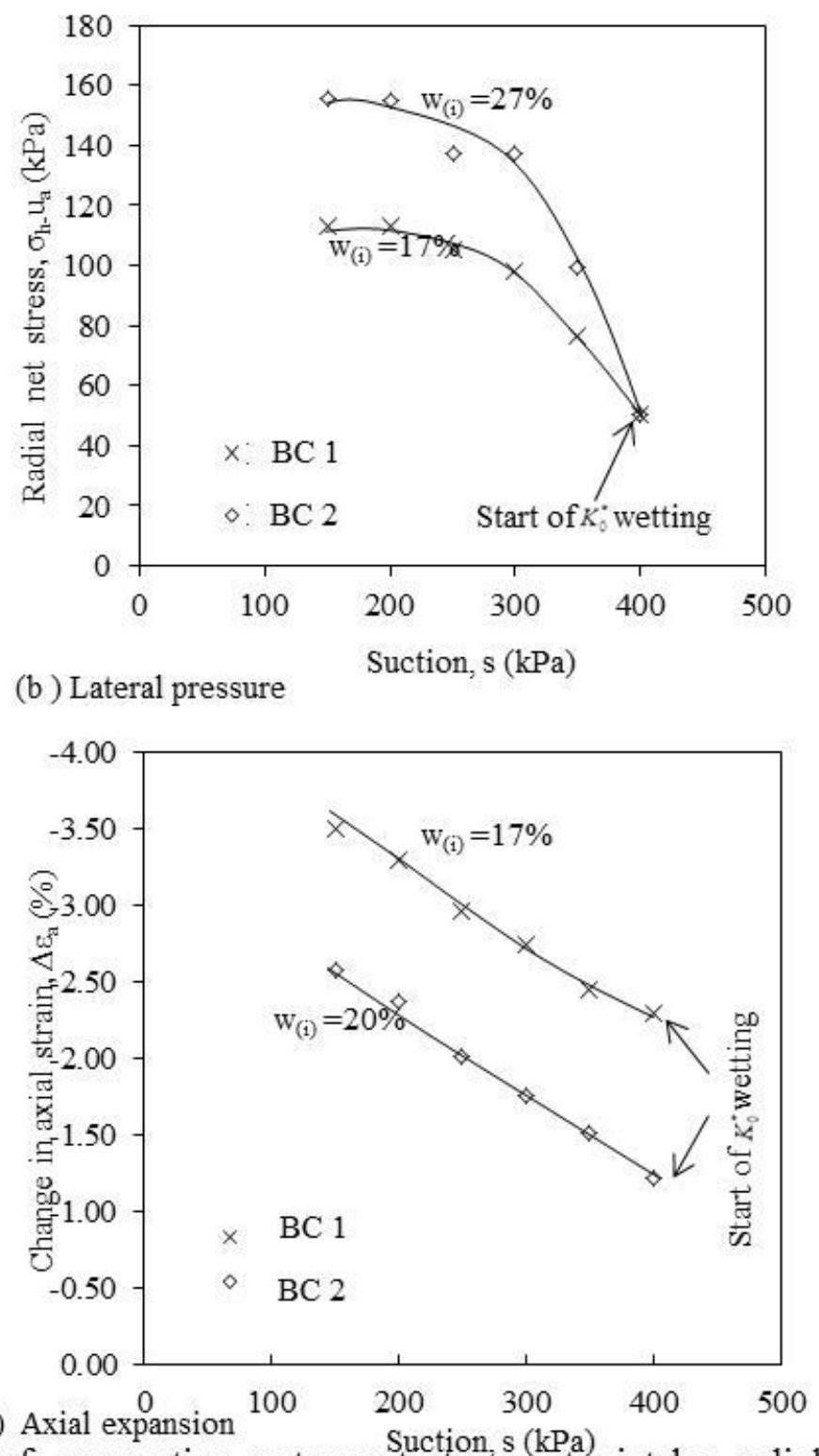

Figure 12 Effect of compaction water content on water intake, radial net stress and axial swelling during $K_{\circ}^{*}$ wetting (BC) 


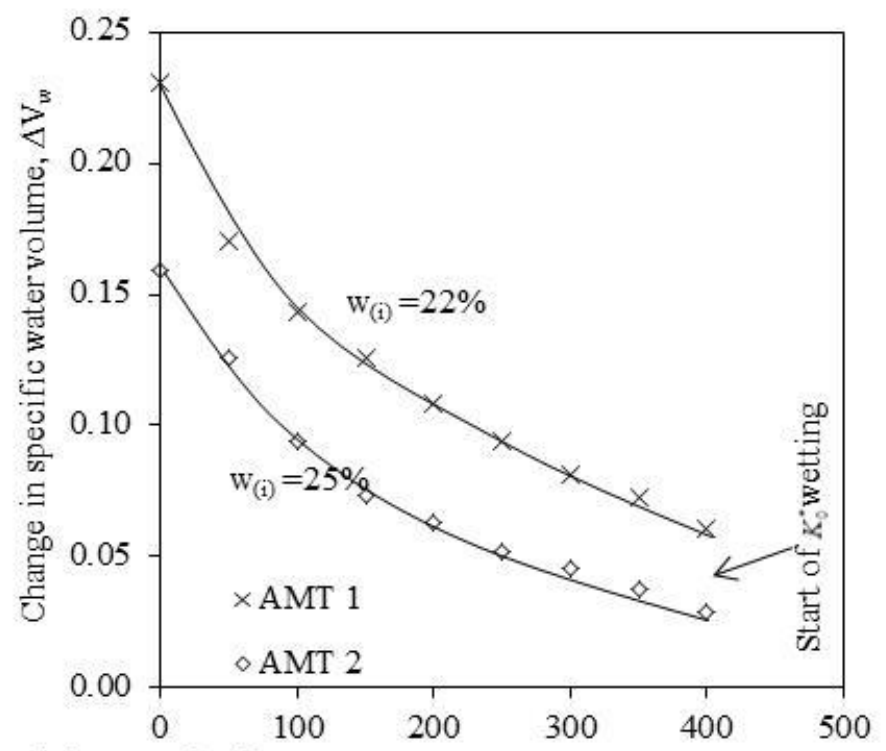

(a) Water-intake Suction, $\mathrm{s}(\mathrm{kPa})$

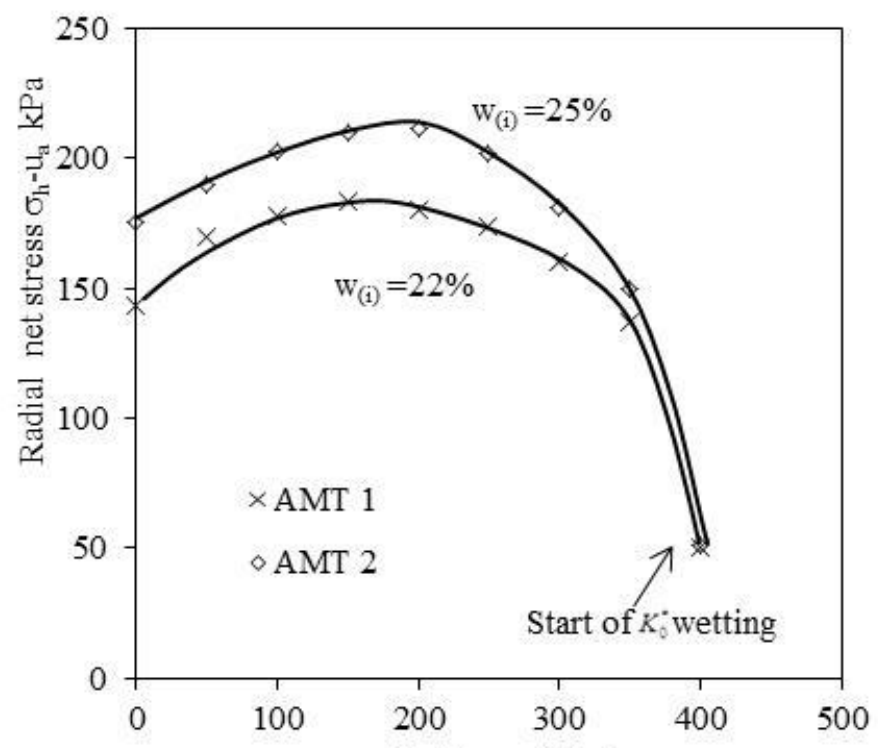

(b) Lateral pressure Suction, $\mathrm{s}(\mathrm{kPa})$

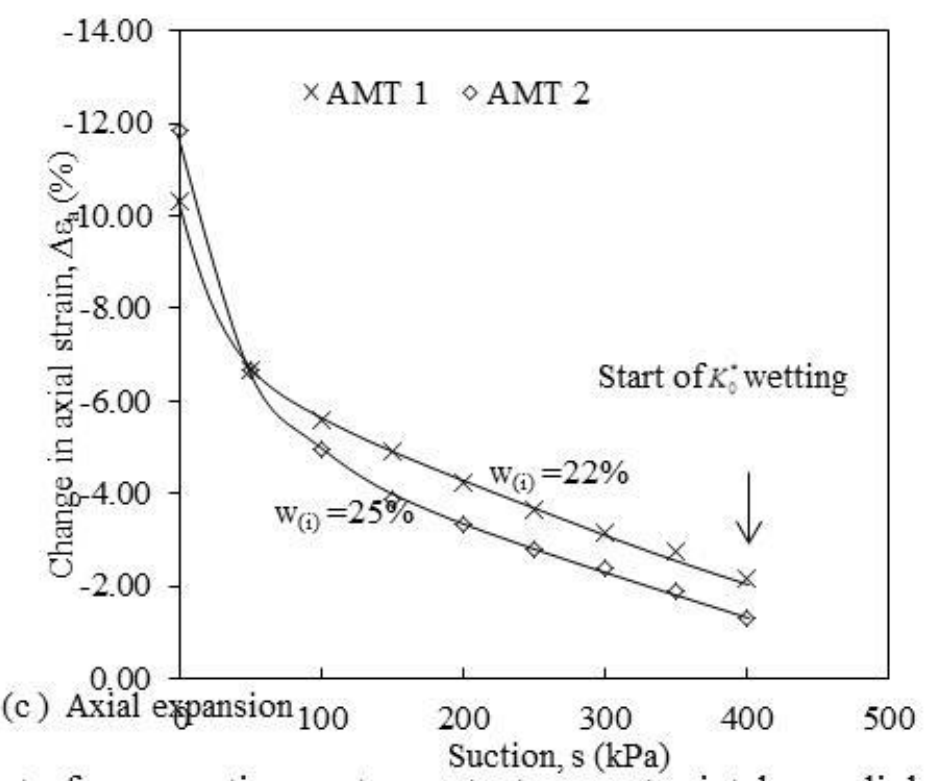

Figure 13 Effect of compaction water content on water intake, radial net stress and axial swelling during $K_{0}^{*}$ wetting (AMT) 


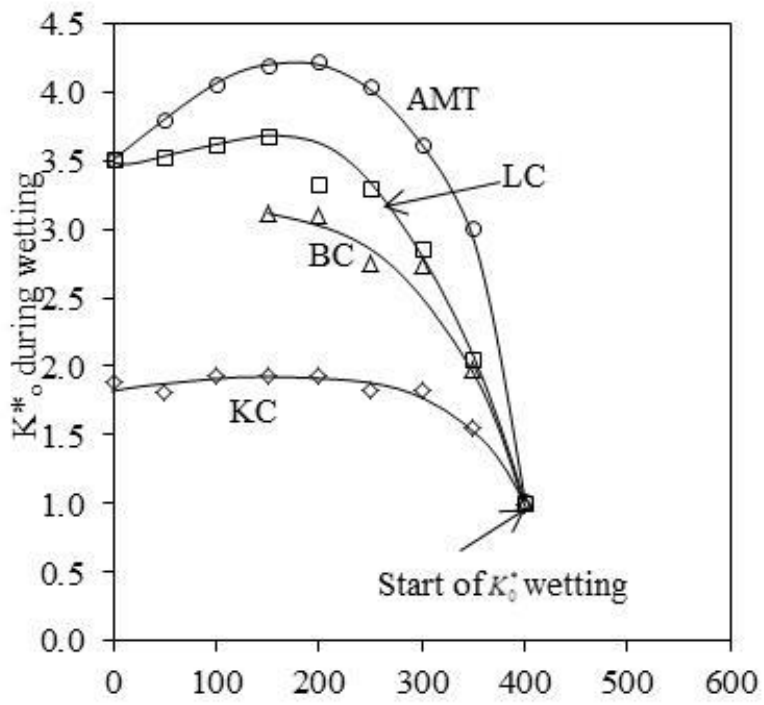

(a) Ko Suction, $\mathrm{s}(\mathrm{kPa})$

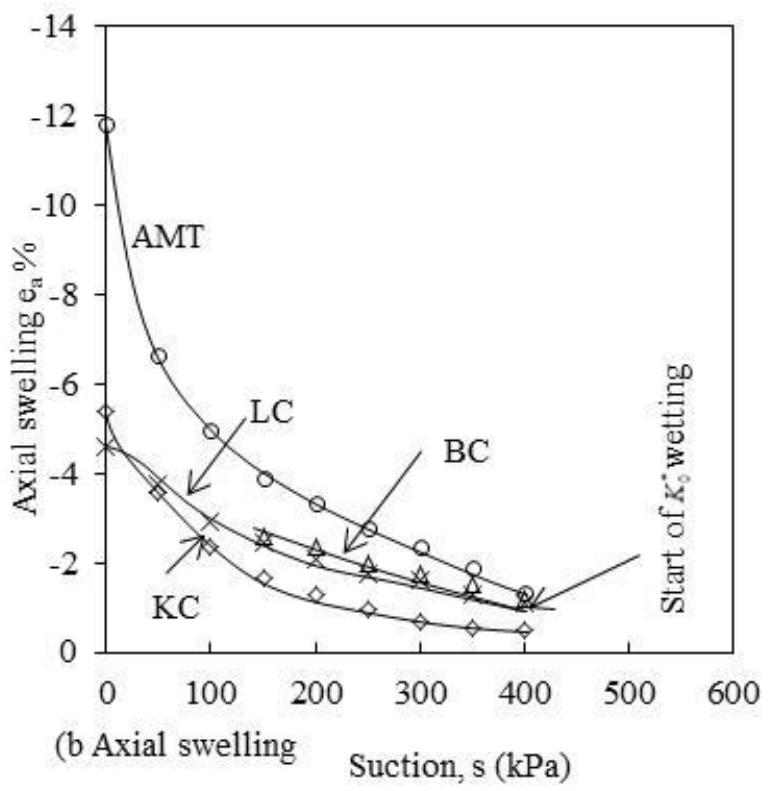

Figure 14 Comparison of $K_{\circ}^{*}$ values and axial swelling during wetting of different clays subjected to the same overburden pressure 


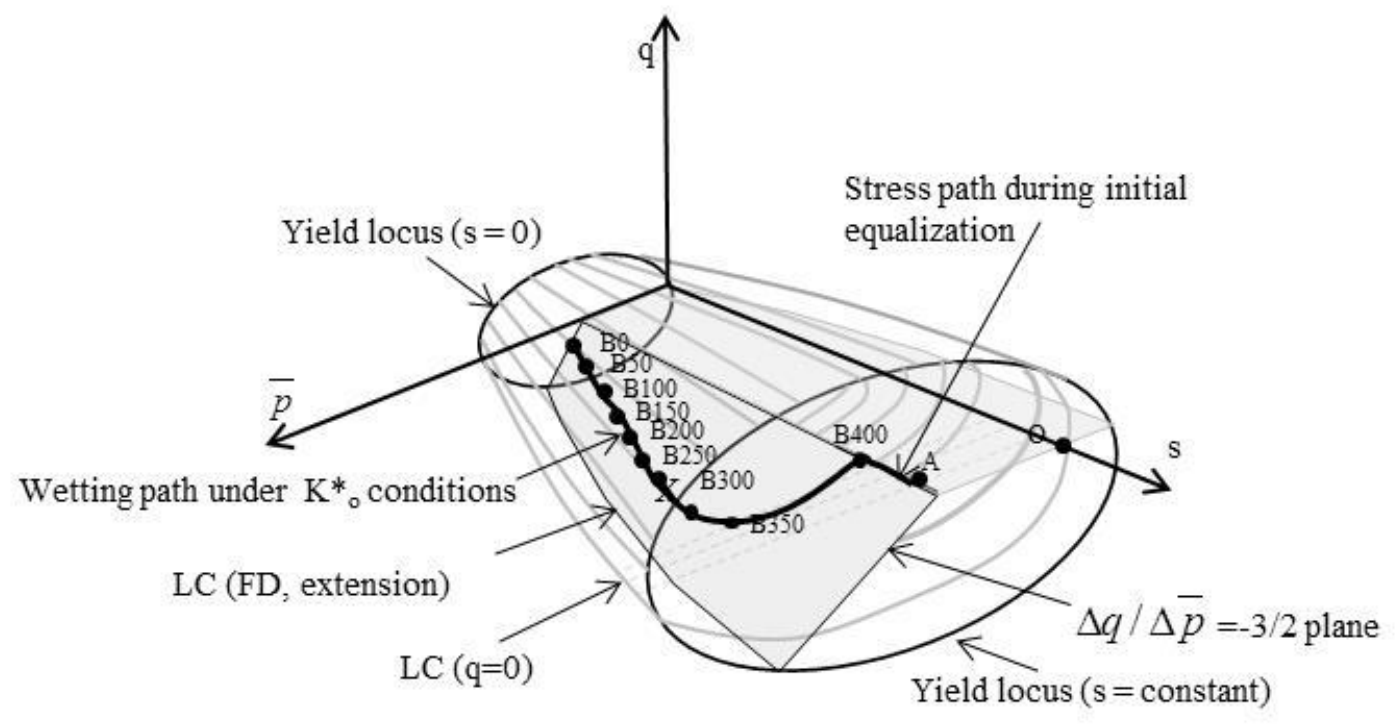

Figure 15 Conceptual modelling and yield surface for Kaolin Clay 


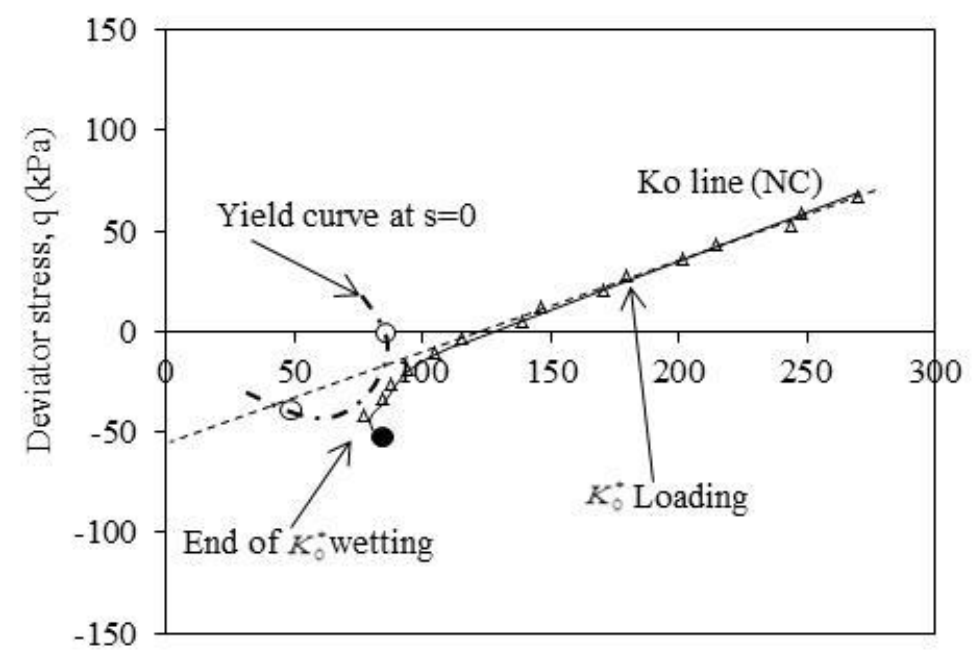

(a) Suction $\mathrm{s}=0 \quad$ Mean net stress $\mathrm{p}-\mathrm{u}_{\mathrm{a}} \mathrm{kPa}$

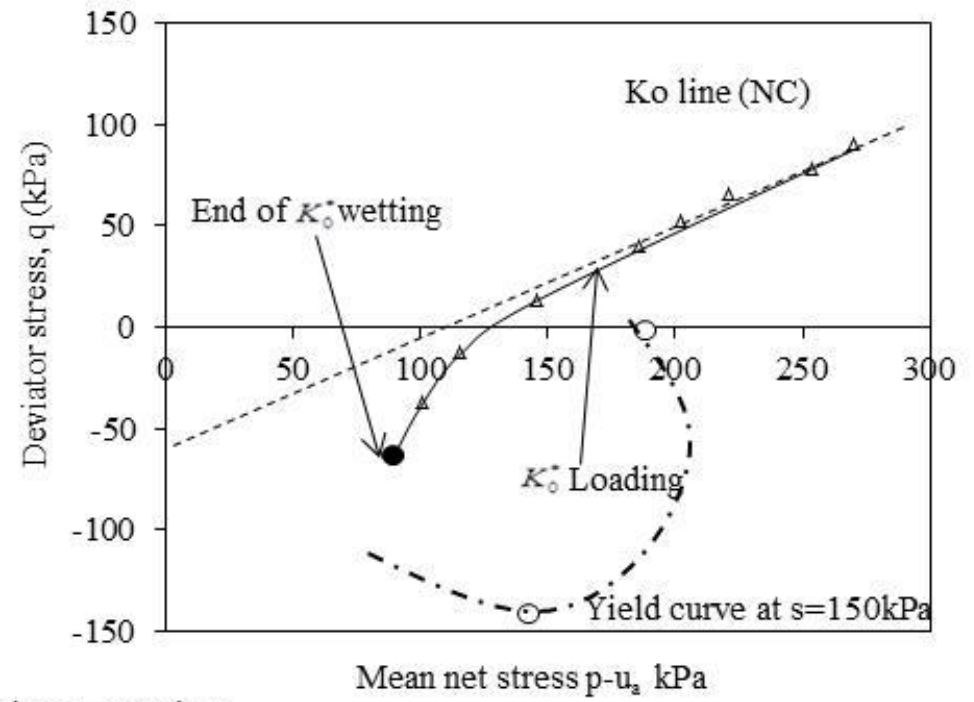

(b) Suction $\mathrm{s}=150 \mathrm{kPa}$

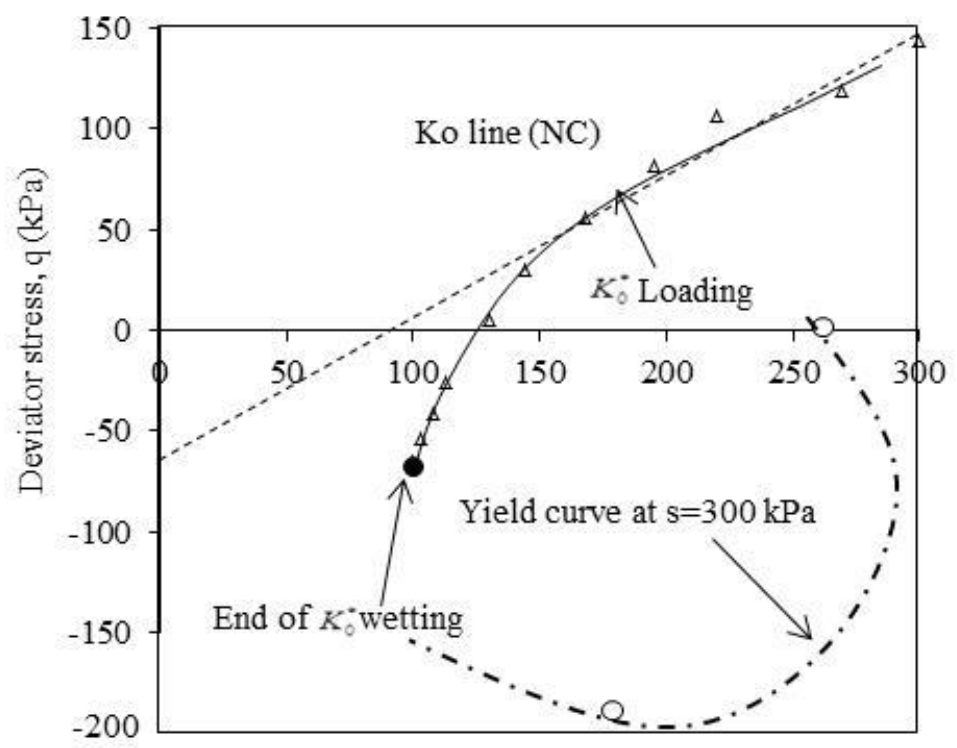

(c) Suction $\mathrm{s}=300 \mathrm{kPa} \quad$ Mean net stress $\mathrm{p}-\mathrm{u}_{\mathrm{a}}(\mathrm{kPa})$

Figure 16 Stress path during $K_{0}^{*}$ loading and yield locus at different suctions $(\mathrm{KC})$ 


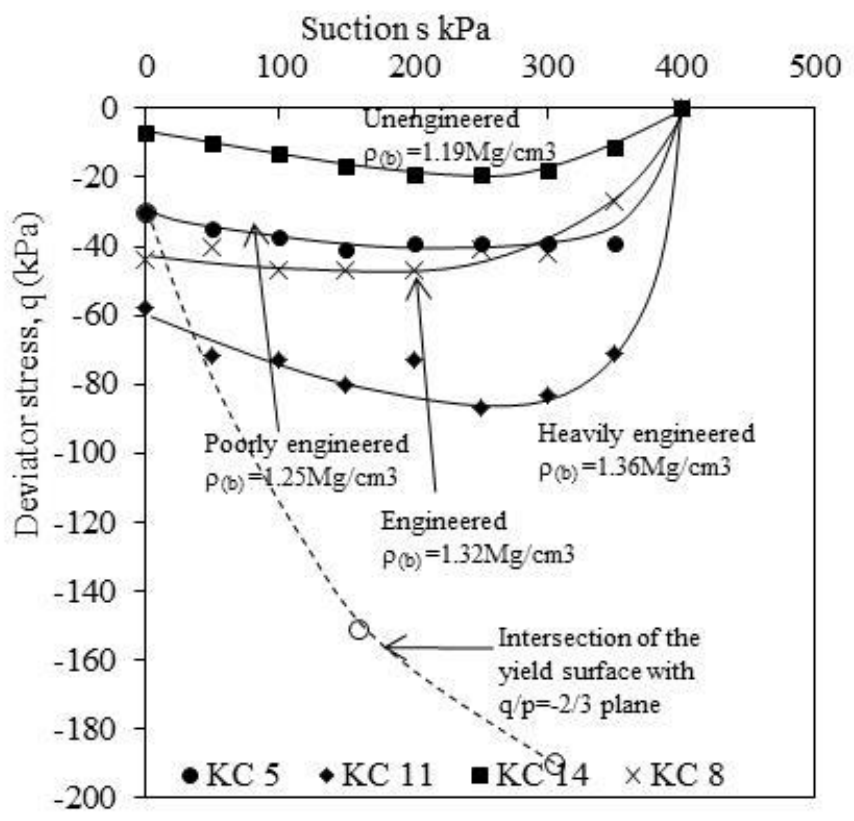

(a) $K_{0}^{*}$ path during wetting in q: s plane

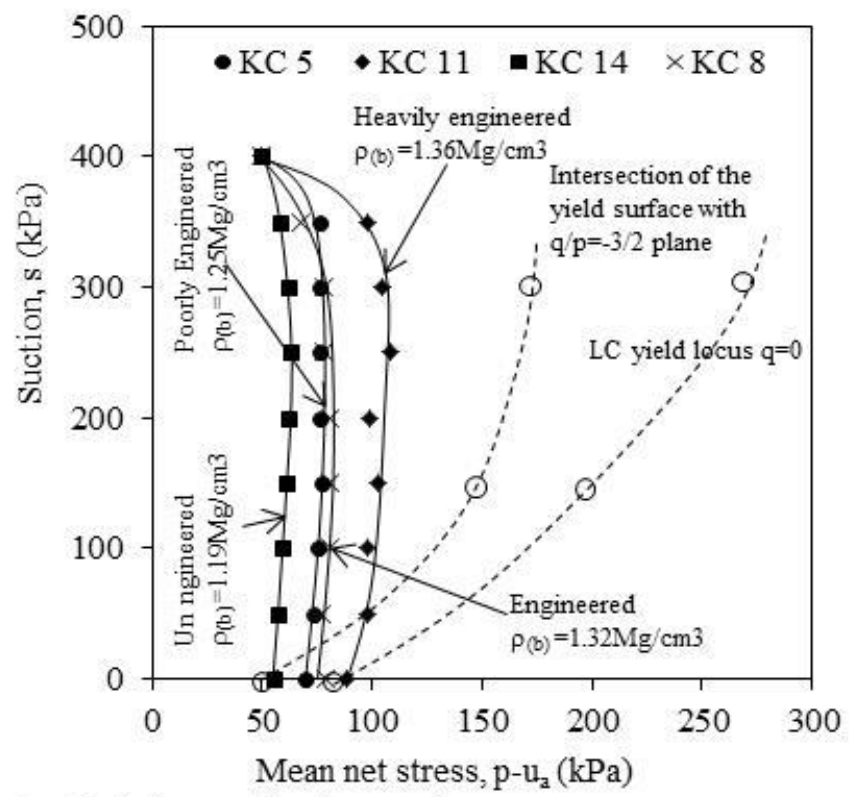

(b) $K_{0}^{*}$ path during wetting in $\mathrm{p}$ : s plane

Figure 17 Stress paths during $K_{0}^{*}$ wetting for Kaolin Clay 